\title{
Methanogenic diversity and activity in hypersaline sediments of the centre of the Napoli mud volcano, Eastern Mediterranean Sea
}

\author{
Cassandre Sara Lazar ${ }^{1}$, R. John Parkes ${ }^{2}$, Barry A. Cragg ${ }^{2}$, Stéphane L'Haridon ${ }^{1}$, Laurent Toffin ${ }^{1, *}$
}

\begin{abstract}
${ }^{1}$ Laboratoire de Microbiologie des Environnements Extrêmes, UMR 6197, Ifremer Centre de Brest, Département Etudes des Environnements Profonds, Université de Bretagne Occidentale, BP70, 29280 Plouzané, France

${ }^{2}$ School of Earth and Ocean Sciences, Cardiff University, Main Building, Park Place, Cardiff CF103YE, UK
\end{abstract}

*: Corresponding author : Laurent Toffin, Tel. (+33) 298224396 ; Fax (+33) 98224757 ;

email address : laurent.toffin@ifremer.fr

\begin{abstract}
:
Submarine mud volcanoes are a significant source of methane to the atmosphere. The Napoli mud volcano, situated in the brine-impacted Olimpi Area of the Eastern Mediterranean Sea, emits mainly biogenic methane particularly at the centre of the mud volcano. Temperature gradients support the suggestion that Napoli is a cold mud volcano with moderate fluid flow rates. Biogeochemical and molecular genetic analyses were carried out to assess the methanogenic activity rates, pathways and diversity in the hypersaline sediments of the centre of the Napoli mud volcano. Methylotrophic methanogenesis was the only significant methanogenic pathway in the shallow sediments $(0-40 \mathrm{~cm})$ but was also measured throughout the sediment core, confirming that methylotrophic methanogens could be well adapted to hypersaline environments. Hydrogenotrophic methanogenesis was the dominant pathway below $50 \mathrm{~cm}$; however, low rates of acetoclastic methanogenesis were also present, even in sediment layers with the highest salinity, showing that these methanogens can thrive in this extreme environment. PCR-DGGE and methyl coenzyme M reductase gene libraries detected sequences affiliated with anaerobic methanotrophs (mainly ANME-1) as well as Methanococcoides methanogens. Results show that the hypersaline conditions in the centre of the Napoli mud volcano influence active biogenic methane fluxes and methanogenic/methylotrophic diversity.
\end{abstract}




\section{INTRODUCTION}

2 Large amounts of the greenhouse gas methane are stored in marine sediments 3 (Kvenvolden, 1988). Methane is also emitted from these sediments, sometimes 4 ascending from deep sources along channels or conduits reaching the seafloor, creating structures such as pockmarks or mud volcanoes. Submarine mud volcanoes are typically found at various tectonically active and passive continental margins, from which mud and fluids (water, brine, gas, oil) flow or erupt (Milkov, 2000). They are considered a significant source of atmospheric carbon, especially methane (Dimitrov, 2003). Mud volcanoes are typically driven by overpressured subsurface sediment in subduction zones of continental margins. They can erupt violently or gently extrude semi-liquid mud-volcano breccia (Dimitrov, 2003). Over 200 mud volcanoes have been found along the northern flank of the Mediterranean Ridge in the eastern Mediterranean Sea (Charlou et al., 2003). The formation of the Mediterranean Ridge is linked to the collision between the African and Eurasian tectonic plates, resulting in intensive faulting (Haese et al., 2006). The Napoli mud volcano is a circular dome situated in the Olimpi area (Fig. 1). This mud volcano has ascending brine fluids characterized by pools and lakes with diameter size ranging from centimeters to meters (Charlou et al., 2003). Fauna are present on the summit (active inner zone), whereas in the outer zone most fauna are dead, suggesting that chemosynthetic activity is limited due to the brines and fluid flows (Olu-Le Roy et al., 2004).

Most of the gas venting from these mud volcanoes is composed of methane, mainly of biogenic origin (Charlou et al., 2003) which is produced by methanogenic Archaea. Methanogenesis is the ultimate terminal oxidation process in the anaerobic degradation of organic matter. Methanogens are divided into three metabolic groups based on substrates used: hydrogenotrophs use $\mathrm{H}_{2} / \mathrm{CO}_{2}$, acetoclasts use acetate, and methylotrophs use methylated compounds (Garcia et al., 2000). Few studies have specifically focused on activity or diversity of methanogens in cold seeps and mud volcanoes (Dhillon et al., 2005; Kendall et al., 2006), and only eight methanogens belonging to six different genera have been cultured and isolated from cold seeps (Sowers et al., 1983, 1984, von Klein, 2002, Mikucki et al., 2003, Shlimon et al., 2004, Singh et al., 2005, Kendall et al., 2006, 2007). Most (>90\%) of the uprising methane is consumed by anaerobic oxidation of methane (AOM) before it 
35 (ANME), and is often coupled to Desulfosarcinales- and Desulfobulbus-related 36 bacteria, as sulfate-reducing partners (Boetius et al., 2000; Knittel et al., 2005; 37 Niemann et al., 2006). Based on the 16S rRNA gene phylogeny, AOM in marine environments is mediated by three distinct clusters of Euryarchaeota, namely ANME1, ANME-2 and ANME-3. These clusters are phylogenetically related to the orders Methanosarcinales and Methanomicrobiales which include cultivated methanogens (Lösekann et al., 2007).

42 The maximum activity of a mud volcano is generally located at the center where 43 methane-rich muds and fluids are freshly expelled from a deep reservoir. In Napoli, methane to ethane ratios and $\delta^{13} \mathrm{CH}_{4}$ values (-65.6\% $\mathrm{PDB}$, Charlou et al., 2003) indicate that methane is biogenic. Napoli mud volcano deep-sourced brine fluids (Charlou et al., 2003) impact on the geochemistry, and thereby, potentially microbial diversity and activities. However, the methanogenic community diversity and activity in the active centers of mud volcanoes has not yet been described. Hence in this study, pathways for biogenic methane production, community structure and activities of methanogens in the center of the Napoli mud volcano were assessed. Rates of the three main metabolic types of methanogenesis were measured, together with the distribution of Archaea, including methanogens by $16 \mathrm{~S}$ rRNA gene PCR-DGGE, as by the functional $m c r A$ gene of methanogens/methanotrophs.

\section{RESULTS and DISCUSSION}

Geochemistry of hypersaline sediments in the center of the Napoli mud volcano.

The temperature at shallow depths of both KUL-3 and KUL-4 gravity cores in the centre of Napoli was an average of $14^{\circ} \mathrm{C}$, with a gradient of $100^{\circ} \mathrm{C} / \mathrm{km}$ (Jean-Paul Foucher, pers. comm.). This value was low compared to high gradients of mud volcanoes of the Nile Deep-Sea Fan (e.g. sediment temperatures were higher than $40{ }^{\circ} \mathrm{C}$ at $10 \mathrm{mbsf}$ at the center of the Isis mud volcano, Feseker et al., 2009), indicating that Napoli is a cold mud volcano with moderate fluid flow rates. Chloride concentrations increased with depth (Fig. 2), from $1578 \mathrm{mM}$ in surface sediments (3 times higher than seawater), to $5085 \mathrm{mM}$ at $122 \mathrm{cmbsf}$ sediment layers ( 10 times higher than seawater). Profiles of the $\mathrm{Mg}^{2+}$ and $\mathrm{Ca}^{2+}$ porewater concentrations

67 (Supplementary Material. SM1) decreased with depth indicating authigenic carbonate 68 precipitation between 0 and $60 \mathrm{cmbsf}$ probably due to anaerobic oxidation of 
methane (AOM) increasing alkalinity (Chaduteau, 2008). The $\mathrm{Na}^{+}$porewater concentrations profile (Supplementary Material. SM1) increased with depth, and was clearly correlated with the $\mathrm{Cl}^{-}$profile. Porewater sulfate concentrations initially decreased rapidly with depth, indicating probable sulfate-reduction as previously suggested (Heijs et al., 2008), until 22 cmbsf where it reached $12 \mathrm{mM}$. Below 22 cmbsf, the sulfate concentration gradually increased (Fig. 2). It has been shown that various electron acceptors, such as sulfate diffuse upwards from deep brines (D'Hondt et al., 2004; Parkes et al., 2005). Hence, the changing sulfate profile at Napoli could also be reasonably explained by a mixing of porewater sulfate with upwards diffusing sulfate-rich brine fluids. Methane was present in the Napoli sediments from about 60 to $130 \mathrm{cmbsf}$ with a peak occurring at $130 \mathrm{cmbsf}$ (Fig. 2). Acetate porewater concentrations were high and overall increased with depth, with $80 \mu \mathrm{M}$ in near-surface sediments (Fig. 2) and maximum concentration at $85 \mathrm{cmbsf}$ $(448 \mu \mathrm{M})$, which overlapped with a broad peak in acetate methanogenesis rates. The acetate concentrations range $(80-448 \mu \mathrm{M})$ were surprisingly high compared not only to seep and non-seep sediments (Newberry et al., 2004; Parkes et al., 2007), but also compared to brine impacted mud volcano sediments in the Gulf of Mexico (maximum $60 \mu \mathrm{M}$, Joye et al., 2009). Concentrations of dissolved inorganic carbon (measured as free $\mathrm{CO}_{2}$ ) increased with depth to a maximum of $8.77 \mathrm{mM}$ at $40 \mathrm{cmbsf}$ (Supplementary Material. SM2), and then returned to shallow sediment concentrations.

\section{Archaeal diversity and depth distribution.}

The DGGE profiles for archaeal 16S rRNA genes (Fig. 3) of DNA from the centre of the Napoli mud volcano had 11 single major bands from 0 to $120 \mathrm{cmbsf}$ depth. This highlights a very low archaeal diversity in these sediments. Sections 40-60 and 100$120 \mathrm{cmbsf}$ had no visible bands. As mcrA genes were successfully amplified from these two sections, it is clear that the $16 \mathrm{~S}$ archaeal primers that were used did not cover all methanogenic or methanotrophic sequences within the Napoli sediments, as mentioned elsewhere (Newberry et al., 2004). Band sequences NapK-dggeB1 to B3, and B5, B6 were affiliated to the methanotrophic ANME-1 group (with 96 to $99 \%$ similarity) in top sections $0-20$ and $20-40 \mathrm{cmbsf}$ (Table 1). Band sequences NapKdggeB7 and B8 were affiliated with the ANME-2 with $98 \%$ similarity, and NapKdggeB9 with the ANME-3 with $98 \%$ similarity in the $60-80$ cmbsf section. Finally 2 
103 band sequences Napk-dggeB4 at 0-20 cmbsf and B10 at 80-100 cmbsf were 104 affiliated with clones of the Marine Benthic Group D (MBG-D) with 100 and 98\%

105

106

107

108

109

110

111

112

113

114

115

116 similarity to sequences from hypersaline sediments of the Gulf of Mexico (Lloyd et al., 2006). Selection of sediment samples for clone libraries of $m c r A$ genes was based on the measured peaks in methanogenic activities (Fig. 2 and Supplementary Material. SM2), at depth sections 40-60, 60-80, and 100-120 cmbsf. A total of $42 \mathrm{mcr} A$ sequences from sediment depths 40 to $60 \mathrm{cmbsf}, 29$ from depths 60 to $80 \mathrm{cmbsf}$, and 40 from depths 100 to $120 \mathrm{cmbsf}$ were analyzed. Rarefaction curves generated for mcrA clones obtained from the 3 sections indicated saturation (Supplementary Material. SM3), while percent coverage was determined to be $87 \%, 73 \%$ and $71 \%$ for 40-60, $60-80$ and 100-120 cmbsf respectively for the clone libraries. The mcrA phylotypes at 40 to 60 and 100 to $120 \mathrm{cmbsf}$ were mainly affiliated with the ANME-1 (mcrA group a/b, Fig. 4). Some sequences were also closely related to the ANME-2a ( $m c r A$ group e) and with methylotrophic methanogens of the Methanococcoides (Fig. 4, Supplementary Material. SM4). In the 60 to $80 \mathrm{cmbsf}$ sediment sections, all mcrA gene sequences were affiliated with the ANME-1 cluster probably involved in the anaerobic oxidation of methane (Fig. 4). ANME-1 sequences were detected in layers 20 to $40 \mathrm{cmbsf}$ where methane concentrations were concave up, and below where sulfate removal was rapid, both typical of an AOM zone and consistent with the authigenic carbonate formation.

DGGE fingerprinting and mcrA clone library analysis showed that ANME-1 were present at all depths, except for the 80-100 cmbsf whereas the same analysis highlighted that ANME-2a were present from 40 to $120 \mathrm{cmbsf}$, with the same exception at 80-100 cmbsf. The ANME-2a subgroup was previously mostly detected in cold seep environment dominated by low fluid fluxes (Mills et al., 2003; Inagaki et al., 2004; Mills et al., 2004; Fang et al., 2006; Niemann et al., 2006), and also in hypersaline sediments in the Chefren mud volcano in the Nile Deep-Sea Fan (Omoregie et al., 2008).

The mcrA group a/b gene of the Napoli mud volcano formed one distinct cluster within the phylogenetic tree. This cluster contained sequences closely affiliated with ANME-1 genes from hypersaline sediments of the Gulf of Mexico with 94 to $97 \%$ of similarity. In their study, Lloyd et al. (2006) identified these ANME-1 as ANME-1b subcluster, and proposed that these ANME-1b could be a high salt adapted subpopulation surviving in an environment where other ANME groups could not. 
137 Also, members of the ANME-1 group have been detected in other environments with 138 high salinities such as a hydrothermal $\left(45^{\circ} \mathrm{C}\right)$ mud vent habitat underneath the deepsea brine lake Urania in the Eastern Mediterranean (Yakimov et al., 2007a), the brine lake of the l'Atalante Basin (Yakimov et al., 2007b), and an Arctic hypersaline 141 perennial spring (Niederberger et al., 2010).

142 Given the very high chloride concentrations in the Napoli sediment sections from 143 which the clone libraries were constructed (i.e. $3000 \mathrm{mM}$ at $40 \mathrm{cmbsf}$, and $4900 \mathrm{mM}$ 144 at $120 \mathrm{cmbsf}$ ) it is possible that the Napoli mcrA a/b sequences belong to the ANME1451 subcluster adapted to high salinity habitats. In the hypersaline sediments of a mud volcano in the Gulf of Mexico, there was no evidence for AOM, even though high methane fluxes were detected (Joye et al. 2009). In contrast, in the Napoli mud volcano sediments there was indirect evidence of AOM occuring in hypersaline sediments, where methane was also present.

\section{Methanogenic activities.}

152 Methanogenic activity using methylamine was the only significant pathway 153 (Supplementary Material. SM2) in the shallow sediment layers (0 to $40 \mathrm{cmbsf}$ ) where sulfate concentrations were maximum and chloride concentrations were at the lowest values. Methylamine methanogenesis turnover rates were more than $10^{2}$ times higher than those for methanol methanogenesis in these same layers. Methanol methanogenesis turnover rates were generally very low but a peak of activity occured at about $50 \mathrm{~cm}$ and in the methane-rich layers, and again at $90 \mathrm{cmbsf}$. Methane production was detected from the same depth interval in non hypersaline media designed to enrich methylotrophic and hydrogenotrophic methanogens (trimethylamine [TMA] and $\mathrm{H}_{2} / \mathrm{CO}_{2}$ ). Total DNA was extracted from $10^{-1}$ and $10^{-2}$ dilution series of the TMA enriched medium inoculated with the $0-20 \mathrm{cmbsf}$ sediment section that produced methane. Phylogenetic affiliation of the $16 S$ rRNA gene sequences NapK-0_20-enr35, and NapK-0_20-enr36 showed 99\% sequence similarity with clone Tommo05_1274_3_Arch90 of the Euryarchaeota (FM179838) from the Tommeliten methane seep, in the North Sea (Wegener et al., 2008), and respectively $97 \%$ and $98 \%$ of sequence similarity with the closest cultured methylotrophic methanogen Methanococcoides methylutens (M59127). Clone NapK80_100-enr37 obtained from the $10^{-1}$ dilution series of the TMA enriched medium of the $80-100$ cmbsf section showed $99 \%$ sequence similarity with Methanococcoides 
171 methylutens (FJ477324). Finally clone Napk-0_20-enr74 from the $10^{-2}$ dilution series 172 of the $\mathrm{H}_{2} / \mathrm{CO}_{2}$ enriched medium at the $80-100 \mathrm{cmbsf}$ section had a $95 \%$ sequence 173 similarity to the carbon dioxide reducing methanogen Methanogenium marinum 174 (NR_028225). However, as enrichments were performed at seawater salinity and not sediment porewater salinity, these methanogens may not represent the in situ 176 halophilic methanogenic community.

177 Culture-dependent and -independent methods were successful in identifying 178 Methanococcoides related methanogens from 0 to $120 \mathrm{cmbsf}$. These methanogens 179 are obligate methylotrophs using only methanol and methylamines as substrates 180 (Garcia et al., 2000). The Sulfate Reducing Bacteria (SRB) outcompete methanogens 181 for substrates such as $\mathrm{H}_{2}$ and acetate in sediments dominated by sulfate-reducing process (Holmer et al., 1994). However, SRB do not compete for methylated substrates that are known to be mostly present in near sediment surfaces (Cetecioglu et al., 2009). Then methylotrophic methanogens are able to outcompete SRB in sulfate-rich marine sediments (Purdy et al., 2003; Dhillon et al., 2005; Roussel et al., 2009). Oremland et al. (1982) reported that methanol and trimethylamines were important substrates for methanogens in salt marsh sediments, dominance of Methanoccoides-type methanogens in sediments of Skan Bay (Kendall et al., 2007) and in sediments of mangroves (Lyimo et al., 2000; Lyimo et al., 2009) were previously reported. Methylamines were also shown to be the main methanogenic catabolic substrate in the hypersaline brine of l'Atalante basin (McGenity, 2010). Pure cutures of methylotrophic methanogens of the Methanohalophilus genus using non competitive substrates such as methylated amines or methanol show higher tolerances to high salinity, up to 24 to $25 \% \mathrm{NaCl}$ (Oren, 1999). Methylotrophic methanogens yields more free-energy $(-191.1 \mathrm{~kJ} / \mathrm{mol}$ of trimethylamine) than acetoclastic $(-31.1 \mathrm{~kJ} / \mathrm{mol}$ of acetate) or hydrogenotroph $(-131 \mathrm{~kJ} / \mathrm{mol}$ of hydrogen) probably allowing methylotrophic methanogens to maintain an osmotically balanced and functional cytoplasm in hypersaline environments (Oren, 1999). Also, various organic osmotic compounds were detected in halophilic methanogens such as 200 glycine betaine, glutamine, $\beta$-glutamate or $\mathrm{N}^{\varepsilon}$-acetyl $\beta$-lysine (Oren, 1999). Zhilina et 201 al. (1990) discovered an halophilic homoacetogen in cyanobacterial mats of Sivash 202 (Crimea) that produces acetate and methylamines from betaine, which are potential 203 catabolic substrates for acetoclastic and methylotrophic methanogenesis.

204 The closest cultivated methylotrophic methanogen was Methanococcoides 
205 alaskense, a psychrophilic strain isolated from Skan Bay in Alaska, having an 206 optimum temperature for growth at $23^{\circ} \mathrm{C}$ (Singh et al., 2005). M. alaskense was also 207 detected in a cold perennial spring of the Canadian high Arctic (Perreault et al., 208 2007). Cells of the type strain M. alaskense, $\mathrm{AK}-5^{\top}$ grew in range of $\mathrm{Na}^{+}$ 209 concentrations below that of seawater. Thus it seems that methylotrophic 210 methanogens of the Methanococcoides are present and adapted for the moderate $211\left(14^{\circ} \mathrm{C}\right)$ temperature and hypersaline sediments of the Napoli mud volcano. Both 212 hydrogenotrophic and acetoclastic methanogenesis activities occured in sediment of 213 the Napoli mud volcano but were generally low. Hydrogenotrophic methanogenesis 214 was the dominant methane formation pathway below $50 \mathrm{cmbsf}$ (Fig. 2), rates being 21525 times higher $\left(14 \mathrm{pmol} \mathrm{cm}^{-3} \mathrm{~d}^{-1}\right)$ than acetoclastic methanogenesis in the same 216 sediment depth (e.g. $70 \mathrm{cmbsf}$ ). Considering competition with the SRB for substrates 217 in the upper layers, it is not surprising to find hydrogenotrophic methanogenesis in 218 the deeper methane-rich sediment layers. Low rates of acetate methanogenesis 219 followed a similar depth trend to hydrogenotrophic methanogenesis with a peak at 70 220 cmbsf $\left(0.6 \mathrm{pmol} \mathrm{cm}^{-3}\right.$ day $\left.^{-1}\right)$. However, a second peak $\left(0.25 \mathrm{pmol} \mathrm{cm}^{-3} \mathrm{day}^{-1}\right)$ of 221 activity occured at $125 \mathrm{cmbsf}$. This similar depth distribution of hydrogenotrophic and 222 acetoclastic methanogenesis was previously reported in two brines from the northern 223 Gulf of Mexico continental slope (Joye et al., 2009). Acetate methanogenesis rates in 224 the Napoli mud volcano were in agreement with those measured in sediments of the 225 Nankai Trough (maximum rate $0.11 \mathrm{pmol} \mathrm{cm}^{-3}$ day $^{-1}$ ) (Newberry et al., 2004). 226 Interestingly, hydrogenotrophic methanogenesis rates were below activity rates 227 measured in other marine sediments (Newberry et al., 2004; Parkes et al., 2007).

228 The presence of methanogenesis activities from hexadecane, a long chain alkane 229 (Supplementary Material. SM2) around $\sim 80 \mathrm{cmbsf}$ demonstrated that methane 230 production from satured hydrocarbons might be significant as previously shown in 231 stable anaerobic enrichments (Zengler et al., 1999). Interestingly, maximum turnover 232 of hexadecane to methane occured at a similar depth to peaks in both 233 hydrogenotrophic and acetotrophic methanogenis rates. A syntrophic association 234 involving methanogens and bacteria to degrade hexadecane to methane most likely 235 would be involved (Dolfing et al., 2008), with acetogenic bacteria decomposing 236 hexadecanes to acetate and $\mathrm{H}_{2}$, which are in turn are available for acetoclastic and 237 hydrogenotrophic methanogens. Grabowski et al. (2005) observed in a low238 temperature and low-salinity petroleum reservoir that homoacetogens were the 
239 dominant cultivated organisms, and that methanogenesis was the dominant terminal 240 process. Acetoclastic and hydrogenotrophic methanogenesis were surmised to be

241 involved in the final step of hydrocarbon degradation in a petroleum hydrocarbon242 contaminated aquifer (Kleikemper et al., 2005). Also, Lloyd et al. (2006) detected 243 sequences possibly related to methanogens in the petroleum-rich and hypersaline 244 methane seep sediments of the Gulf of Mexico. Schulz et al. (1997) showed that the 245 sediments mobilized in the Napoli mud volcano were characterized by gaseous 246 hydrocarbons, and that the sediments comprising the mud breccia originated from 2474900 to 7500 mbsf. Hence, the Napoli mud volcano probably displays a wide range 248 of substrates producing methane, including deep sourced petroleum.

249 Overall, PCR-DGGE and mcrA gene analysis demonstrated the presence of ANME2501,2 and 3 clusters in sediments where hydrogenotrophic and acetoclastic 251 methanogenesis rates were measured, suggesting that AOM is probably also present 252 and active. $\mathrm{CO}_{2}$ produced by anaerobic methane oxidation mediated by ANME, plus 253 AOM metabolic intermediates could be available for the hydrogenotrophic 254 methanogenesis thus enhancing methane production (Parkes et al., 2007). Sulfate255 reducing bacteria can be inhibited by high salinities (Brandt et al. 2001), which may 256 enable methanogens to occur even in the presence of high sulfate concentrations, as 257 in the Napoli mud volcano sediments.

258 Below $100 \mathrm{cmbsf}$, acetoclastic methanogenesis was the dominant pathway for 259 methane production. Hence, a shift from hydrogenotrophic to acetoclastic 260 methanogenesis occured. Bicarbonate can also be converted to acetate by 261 acetogens (Zepp Falz et al., 1999). Acetogens were found to be important 262 competitors of hydrogenotrophic methanogens in a low-sulfate hypersaline microbial 263 mat collected from salterns in Baja (Kelley et al., 2006). Also, halophilic 264 homoacetogens were reported in cyanobacterial mats, capable of producing acetate 265 from betaine, or bicarbonate (Zhilina et al., 1990). Even though the acetogenic 266 reaction yields less energy than the actoclastic reaction, the halophilic 267 homoacetogens of the order Haloanaerobiales have been shown to use an 268 enegertically more efficient option to adapt to high salinity environments (Oren et al., 269 1999). Interestingly, acetate concentrations increased by $\sim 80 \mathrm{cmbsf}$ in Napoli 270 porewaters (Fig. 2). Thus, the presence of halophilic homoacetogens below $~ 80$ 271 cmbsf could explain the absence of hydrogenotrophic methanogenesis, the increase 
272 of acetate concentrations and the switch to acetoclastic methanogenesis in these 273 sediment layers.

Influence of environmental factors on archaeal community composition in the 276 Napoli sediments.

277 Sediments (down to $120 \mathrm{cmbsf}$ depth) of the Napoli mud volcano center were 278 characterized by very high chloride concentrations (from $1.5 \mathrm{M}$ to $5 \mathrm{M}$ ), low stable 279 temperatures, and presumably moderate fluid flows. Total prokaryotic cell numbers 280 (Fig. 5) and percentage of dividing and divided cells were relatively low in the shallow 281 sediments $\left(1.49 \times 10^{8} \mathrm{~cm}^{-3}\right.$ and $11 \%$ respectively), compared to the total prokaryotic 282 depth distribution (Parkes et al., 2000). Microbial abundance strongly decreased with 283 depth, reaching $5.5 \times 10^{6} \mathrm{~cm}^{-3}$ at $150 \mathrm{cmbsf}$. Only a limited number of prokaryotes 284 can cope with the hypersaline conditions of the Napoli mud volcano sediments which 285 explains the decrease in prokaryotic cell numbers with depth. However, within the 286 upper overlap between sulfate and methane ( 20 to $60 \mathrm{cmbsf}$, Fig. 2), there is a clear 287 increase in total cell numbers above this decreasing trend (Fig. 5), which suggests 288 active AOM (Parkes et al., 2005) and is consistent with the presence of ANME-1 289 sequences (Table 1).

290 Although microbial abundance generally decreased with increasing chloride 291 concentrations, methanogenic activities in the centre of Napoli mud volcano (Charlou 292 et al., 2003) were comparable to those measured in subsurface sediments (Webster 293 et al., 2008), but lower than rates of methanogenesis in Mediterranean brines and 294 Gulf of Mexico (Joye et al., 1999; van der Wielen et al., 2005; Daffonchio et al., 295 2006). This could be linked to the ascending fluid flows in the center of the mud 296 volcano, that could hinder efficient methanogenesis. Three factors are known to 297 influence methanogenic pathways: salinity, temperature and availability of substrates 298 (Zepp Falz et al., 1999; Glissmann et al., 2004; McGenity, 2010). Salinity is a major 299 factor in determining microbial community structure, and hypersaline sediments can 300 be phylogenetically more diverse than other environments (Lozupone et al., 2007). 301 However, saline gradients are composed of a number of electron acceptors, donors, 302 nutrients, and carbon sources available for the microorganisms (McGenity, 2010). In 303 addition, salinity may indirectly control substrate availablity for methanogens, by 304 controling the diversity of organisms producing their substrates (i.e., halophilic 305 acetogens and fermenters producing acetate and methylamines). Traditionally, high 
306 salinity is thought to favour hydrogenotrophic and methylotrophic methanogenesis, 307 because acetoclastic methanogens cannot tolerate these extrême halophilic 308 conditions (>60 \% salinity) (Oren, 1999). However, acetoclastic methanogenesis does occur in Napoli sediments, and at depths where chloride concentrations are higher than $4 \mathrm{M}(>140 \%$ \%). Acetoclastic methanogenesis at a salinity exceeding $60 \%$ o 311 has already been reported in brine sediments of a mud volcano in the Gulf of Mexico 312 (Joye et al., 2009), demonstrating that some acetoclastic methanogens have adapted 313 to high salinity environments. In contrast, uncutivated archaeal sequences affiliated 314 with the MBG-D have been detected in many saline and hypersaline environments 315 (Benlloch et al., 2002; Sorensen et al., 2005; Lloyd et al., 2006; Jiang et al., 2008; 316 Omoregie et al., 2008). Jiang et al. (2008) propose that high salinity and alkalinity, 317 among other unknown factors, could play an important role in controlling the 318 distribution of marine benthic groups, such as the MBG-D. Hence the hypersaline 319 regime in the Napoli center sediments could have influenced establishment of these 320 MBG-D populations.

321 Studies conducted on lake sediments show that a shift from 4 to $20^{\circ} \mathrm{C}$ induces a shift 322 from acetoclastic to hydrogenotrophic methanogenesis (Zepp Falz et al., 1999; 323 Glissmann et al., 2004). Indeed Schulz et al. (1997) hypothesize that in lake sediments at low temperatures, hydrogenotrophic methanogens are limited by the lack of supply of $\mathrm{H}_{2}$, which is linked with the idea that $\mathrm{H}_{2}$-producing syntrophs are sensitive to low temperatures. In the Napoli sediments, the temperature at $70 \mathrm{cmbsf}$ was around $14^{\circ} \mathrm{C}$ which could be one factor explaining why overall hydrogenotrophic methanogenesis is higher than acetoclastic methanogenesis. In this context, Napoli sediments are similar to other marine sediments as these are also dominated by hydrogenotrophic methanogenesis (Whiticar et al., 1986).

331 Therefore, the brine affected Napoli mud volcano in the Mediterranean Sea represents a dynamic ecological niche for methanogens and other prokaryotes that have to adapt to variations in fluid flow and composition, and high salinity.

\section{EXPERIMENTAL PROCEDURES}

\section{Site description and sediment sampling.}

337 Sediment cores were collected from the center of the Napoli mud volcano at 1940 metres of water depth (Fig. 1) in the Eastern Mediterranean Sea, during the Ifremer MEDECO cruise with the research vessel Pourquoi Pas? in October/November 2007. 
340 Two gravity cores KUL-3 $\left(33^{\circ} 43.497^{\prime} \mathrm{N}, 2^{\circ} 41.1648^{\prime} \mathrm{E}\right)$ and KUL-4 $\left(33^{\circ} 43.508^{\prime} \mathrm{N}\right.$, $\left.34124^{\circ} 41.1549^{\prime} \mathrm{E}\right), 160 \mathrm{~cm}$ and $120 \mathrm{~cm}$ in length, respectively, were obtained. 342 Temperature gradients were measured using sensors attached to the gravity cores. 343 Immediately after retrieval, the KUL-3 and KUL-4 cores were sectioned aseptically in 34420 -cm-thick layers in a cold room $\left(4^{\circ} \mathrm{C}\right)$, and mini-cores of sediment were removed 345 for gas and molecular analysis. Samples for molecular analysis were collected by 346 using cut-off sterile $5 \mathrm{~mL}$ syringes in the $20 \mathrm{~cm}$ sediment sections of KUL-4 and were 347 frozen at $-80^{\circ} \mathrm{C}$ for nucleic acid extractions. For the KUL-3 core, $20 \mathrm{~cm}$ sections were 348 flushed with nitrogen, hermetically sealed in aluminium bag-rolls (Grüber-Folien, 349 Germany), and transported to the laboratory at $4^{\circ} \mathrm{C}$ for subsequent methanogenesis 350 rate measurements and pore water analysis.

\section{Biochemistry.}

353 Porewater was obtained by centrifuging approximately $10 \mathrm{~g}$ of sediment for 15 354 minutes at $3000 \times \mathrm{g}$ at $4{ }^{\circ} \mathrm{C}$. The porewater was then stored at $-20^{\circ} \mathrm{C}$ until required. 355 Depth distribution of dissolved cations were quantified from diluted and filtrated porewater by using ion exchange chromatography, as described below. Cation concentrations were measured using an isocratic DX120 ion chromatography system (DIONEX Corporation, Sunnyvale, CA) fitted with lonpac CS 12A columns and a supressor (CSRS-ultra II) unit in combination with a DS4-1 heated conductivity cell. Components were separated using a methasulfonic acid $(18 \mathrm{mM})$ gradient, with a flow of $1 \mathrm{~mL} \mathrm{~min}^{-1}$.

Pore water sulfate and acetate concentrations were measured by ion exchange chromatography using an ICS-2000 ion chromatography system (Dionex ${ }^{\circledR}$, UK) fitted with two AS15-HC $4 \mathrm{~mm}$ columns inseries, and a Dionex ${ }^{\circledR}$ Anion Self-Regenerating Suppressor(ASRS ${ }^{\circledR}$-ULTRA I| 4-mm) unit in combination with a Dione ${ }^{\circledR}$ DS6 heated conductivity cell. Components were separated using a potassium hydroxide gradient program as follows: $6.0 \mathrm{mM} \mathrm{KOH}$ (38 min isocratic), $16.0 \mathrm{mM} \mathrm{KOH} \mathrm{min-1}$ to $70 \mathrm{mM}$

369 Methane concentrations were determined from $3 \mathrm{~cm}^{3}$ sediment sample sealed in glass tubes containing $6 \mathrm{~mL} \mathrm{NaOH}(2.5 \% \mathrm{w} / \mathrm{v})$, on board using the headspace

371 technique coupled with a gas chromatograph GC (HSS-GC) equipped with a thermalconductivity detector (TCD) and a flame-ionisation detector (error of $4 \%$ ). Helium was

373 the carrier gas, and column temperature was $40^{\circ} \mathrm{C}$ (details in Sarradin et al., 1996). 
375 Methanogenesis rate measurements.

376 Radiotracer experiments using ${ }^{14} \mathrm{C}$ labelled substrates were conducted in the 377 laboratory at Cardiff University, UK according to Parkes et al. (2007) using the $4^{\circ} \mathrm{C}$ 378 stored cores. Intact $5 \mathrm{~mL}$ syringe subcores were taken in the center of core, and 379 sealed with sterile Suba Seals (Sigma-Aldrich, Missouri, USA). These samples were 380 separately injected with radiotracers $\left(\left[{ }^{14} \mathrm{C}\right]\right.$ bicarbonate, $\left[{ }^{14} \mathrm{C}\right]$ acetate, $\left[{ }^{14} \mathrm{C}\right]$ methanol $381\left[{ }^{14} \mathrm{C}\right]$ methylamine or $\left[{ }^{14} \mathrm{C}\right]$ hexadecane) and incubated at close to in situ temperatures $382\left(15^{\circ} \mathrm{C}\right)$. Activity was then stopped by freezing before processing in the laboratory. 383 Methane production rates were calculated based on the proportion of labelled gas 384 produced from the ${ }^{14} \mathrm{C}$-substrate, and the measured porewater substrate 385 concentration adjusted for sediment porosity and incubation time $\left(\left[{ }^{14} \mathrm{C}\right]\right.$ acetate, 386 methanol and methylamine $-15-20 \mathrm{~h} ;\left[{ }^{14} \mathrm{C}\right]$ bicarbonate and hexadecane $\left.-40-46 \mathrm{~h}\right)$. 387 Methanol, methylamine and hexadecane methanogenic rates were expressed as 388 turnover rates as their porewater concentrations were unknown. Because incubation 389 conditions were not identical to conditions in the original sediment, measured rates 390 might differ from those in situ.

\section{Acridine Orange Direct Counts}

393 Total prokaryote numbers were determined by AODC counts as previously described 394 (Parkes et al., 2005). Trends and peaks in rate and AODC data were assessed by 395 analysis of variance, the sum of squares simultaneous test procedure and the 396 Moodmedian test, as appropriate using Mini-Tab 14.2.

\section{Culture media for enrichment of methanogens.}

399 One volume of sediment subsample $\left(10 \mathrm{~cm}^{3}\right)$ was transferred into an anaerobic 400 cabinet and then into $50 \mathrm{~mL}$ vials containing one volume $(10 \mathrm{~mL})$ of sterile and 401 reduced Artificial Sea Water (ASW). ASW corresponded to medium 141 of DSMZ 402 devoid of organic carbon substrates. The sediment slurries were further reduced with $403 \mathrm{Na}_{2} \mathrm{~S}$ if necessary and stored at $4^{\circ} \mathrm{C}$ until processing. Enrichment were performed 404 anaerobically in $50 \mathrm{~mL}$ vials according to Balch and Wolfe (1976). Medium 141 from 405 the DSMZ was used with slight modifications : organic substrates were omitted 406 except yeast extract which was adjusted to $0.2 \mathrm{~g} \mathrm{~L}^{-1}$. The medium was prepared and 
407 sterilized under $80 \quad \mathrm{~N}_{2}$ and $20 \% \quad \mathrm{CO}_{2}$ gas atmosphere. In order to enrich $\mathrm{CO}_{2}{ }^{-}$ 408 reducing, aceticlastic and methylotrophic methanogens, three enrichment media 409 supplemented with $\mathrm{H}_{2}(200 \mathrm{kPa})$, acetate $(10 \mathrm{mM})$, trimethylamine (TMA, $\left.20 \mathrm{mM}\right)$ 410 were used. One gram of sediment from the different sections of the KUL-4 core were 411 inoculated into $9 \mathrm{~mL}$ of medium ( $\mathrm{pH} 7)$. The suspension was mixed and serially 412 diluted until $10^{-3}$. The enrichments were incubated at close to in situ temperature of $41315^{\circ} \mathrm{C}$. Cultures were periodically checked for methane production for one year. The 414 methane detection was performed directly in the headspace of vial cultures by a 415 micro MTI M200 Gas Chromatograph equipped with MS-5A capillary column and 416 Poraplot $U$ capillary column. Positive enrichment dilutions of methanogens were 417 monitored by microscopic observation under UV-light and PCR-DGGE. For dilutions 418 showing one DGGE band, 16S rRNA genes were amplified using the A8F and 419 A1492R primers (Casamayor et al., 2000), cloned and sequenced as subsequently 420 described.

\section{DNA extraction and purification.}

423 Total genomic DNA was directly extracted and purified from $5 \mathrm{~g}$ of wet sediment for 424 all 20-cm-thick sections in duplicates, by using the Zhou et al. (1996) method with 425 modifications. Sediment samples were mixed with DNA extraction buffer as 426 described by Zhou et al., and then frozen in liquid $\mathrm{N}_{2}$ and thawed at $65^{\circ} \mathrm{C} 3$ times. 427 The pellet of crude nucleic acids obtained after centrifugation, was washed with cold 428 80\% ethanol, and resuspended in sterile deionized water, to give a final volume of $429100 \mu \mathrm{L}$. Crude DNA extracts were then purified using the Wizard DNA clean-up kit 430 (Promega, Madison, WI). DNA extracts were aliquoted and stored at $-20{ }^{\circ} \mathrm{C}$ until 431 required for $\mathrm{PCR}$ amplification.

\section{PCR-DGGE amplification of total DNA.}

434 Archaeal 16S rRNA genes were amplified by PCR from purified DNA extracts using 435 the Archaeal targeted primers pair 8F (5'-CGGTTGATCCTGCCGGA-3') and 1492R 436 (5'-GGCTACCTTGTTACGACTT-3') (Casamayor et al., 2000). All PCR reactions 437 (total volume reaction $25 \mu \mathrm{L}$ ) contained $1 \mu \mathrm{L}$ purified DNA template (1/25 dilution), 1 $438 \times$ PCR buffer (Promega, Madison, WI), $2 \mathrm{mM} \mathrm{MgCl}_{2}, 0.2 \mathrm{mM}$ of each dNTP, $0.4 \mathrm{mM}$ 439 of each primer (Eurogentec) and 0.6 U GoTaq DNA polymerase (Promega, Madison, 440 WI). Amplification was carried out using the GeneAmp PCR 9700 System (Applied 
441 Biosystems, Foster City, CA). The PCR conditions were as follows: denaturation at $44294^{\circ} \mathrm{C}$ for $1 \mathrm{~min}$, annealing at $49^{\circ} \mathrm{C}$ for $1 \mathrm{~min} 30 \mathrm{~s}$, and extension at $72^{\circ} \mathrm{C}$ for 2 min for 44330 cycles. All the archaeal 16S rRNA gene PCR products were then re-amplified with 444 primers 340F (5'-CCCTACGGGGYGCASCAG-3') (Vetriani et al., 1999) containing a 445 GC clamp (5'-CGCCCGCCGCGCCCCGCGCCCGTCCCGCCGCCCCCGCCCG-3') 446 at the 5' end and 519R (5'-TTACCGCGGCKGCTG-3') (Ovreas et al., 1997). The 447 PCR conditions were as follows: denaturation at $94^{\circ} \mathrm{C}$ for $30 \mathrm{~s}$, annealing at $72^{\circ} \mathrm{C}$ to $44862^{\circ} \mathrm{C}$ (touchdown $-0.5^{\circ} \mathrm{C}$. cycle $^{-1}$ ) for $30 \mathrm{~s}$, and extension at $72^{\circ} \mathrm{C}$ for $1 \mathrm{~min}$, for 20 449 cycles, then denaturation at $94^{\circ} \mathrm{C}$ for $30 \mathrm{~s}$, annealing at $62^{\circ} \mathrm{C}$ for $30 \mathrm{~s}$, and extension 450 at $72^{\circ} \mathrm{C}$ for $1 \mathrm{~min}$, for 10 cycles, final extension at $72^{\circ} \mathrm{C}$ for $30 \mathrm{~min}$ (Janse et al., 451 2004).

452 To restrict contamination to a minimum, PCR experiments was carried out under 453 aseptic conditions (Captair ${ }^{\circledR}$ bio, Erlab, Fisher Bioblock Scientific) using autoclaved 454 and UV-treated plasticware and pipettes, and only sterile nuclease-free molecular 455 grade water (MP Biomedicals, Solon, OH, USA). Positive (DNA extracted from pure 456 cultures) and negative (molecular grade water) controls were used in all PCR 457 amplifications.

DGGE fingerprinting analysis, band excision and sequencing.

460 DGGE was carried out as described by Webster et al. (2003) with some 461 modifications. PCR products were separated by DGGE using the D-Gene ${ }^{\mathrm{TM}}$ System 462 (Bio-Rad Laboratories, Hercules, CA) on 8\% (w/v) polyacrylamide gels $(40 \%$ 463 acrylamide/bis solution 37.5:1 Bio-Rad) with a linear gradient of urea and formamide 464 between $20 \%$ and 60\% (100\% denaturing conditions are defined as $7 \mathrm{M}$ urea and $46540 \%(\mathrm{v} / \mathrm{v})$ formamide). Gels were poured with the aid of a $30 \mathrm{~mL}$ volume Gradient 466 Mixer (Hoefer SG30, GE Healthcare, Buckinghamshire, UK) and prepared with $1 \mathrm{X}$ 467 TAE buffer (MP Biomedicals, Solon, OH, USA). Electrophoresis was carried out at $46860^{\circ} \mathrm{C}, 200 \mathrm{~V}$ for 5 hours (with an initial electrophoresis for $10 \mathrm{~min}$ at $80 \mathrm{~V}$ ) in $1 \mathrm{X}$ TAE 469 buffer. Polyacrylamide gels were stained with SYBRGold nucleic acid gel stain 470 (Invitrogen, San Diega, CA) for $30 \mathrm{~min}$, and viewed using the Typhoon 9400 Variable 471 Mode Imager (GE Healthcare, Buckinghamshire, UK). Individual DGGE bands of 472 interest were excised and washed in sterile-nuclease free molecular grade water for $47310 \mathrm{~min}$. Bands were then air-dried and crushed in 10-20 $\mu \mathrm{L}$ molecular grade water 474 and incubated overnight at $4^{\circ} \mathrm{C}$. The supernatent $(1 \mu \mathrm{L})$ was used as template DNA in 
475 a nested PCR using primer set 340F and 519R. The PCR products of excised DGGE 476 bands were sequenced with primer 519R, using an ABI PRISM 3100-Genetic 477 Analyzer (Applied Biosystems, Foster City, CA) at the Biogenouest ${ }^{\circledR}$ plateform of 478 Roscoff Marine laboratory (France).

479

480 mcrA PCR amplification, and cloning.

481 Genes coding for the alpha subunit of the methyl- coenzyme M-reductase's (mcrA) 482 were amplified using the ME1 (5'-GCMATGCARATHGGWATGTC-3') and ME2 (5'483 TCATKGCRTAGTTDGGRTAGT-3') primers (Hales et al., 1996). The PCR conditions 484 were as follows: denaturation at $94^{\circ} \mathrm{C}$ for $40 \mathrm{~s}$, annealing at $50^{\circ} \mathrm{C}$ for $1 \mathrm{~min} 30 \mathrm{~s}$, and 485 extension at $72^{\circ} \mathrm{C}$ for 3 min for 30 cycles. PCR products were purified with the 486 QIAquick Gel Extraction kit (QIAGEN, Hilden, Germany) and analyzed on 1\% (w/v) 487 agarose gels run in 1 X TAE buffer stained with ethidium bromide and then UV488 illuminated. Purified PCR products were cloned into TOPO ${ }^{\circledR}$ XL PCR Cloning Kit, and 489 transformed into Escherichia coli TOP10 One Shot ${ }^{\circledR}$ cells (Invitrogen, San Diego, CA) 490 according to the manufacturer's recommendations.

492 DNA sequencing and phylogenetic analysis.

493 16S rRNA and mcrA gene sequences were obtained using BigDye terminator 494 chemistry and determined on a ABI PRISM 3100-Genetic Analyzer automated 495 capillary sequencer (Applied Biosystems, Foster City, CA). Cloned 16S rDNA and 496 mcrA gene fragments were sequenced using the M13 reverse primer (5'497 CAGGAAACAGCTATGAC-3') universal primer and analyzed using the NCBI 498 BLASTN search program within GeneBank (http://blast.ncbi.nlm.nih.gov/Blast) 499 (Altschul et al., 1990). The presence of chimeric sequences in the clone libraries was 500 determined with the CHIMERA CHECK program of the Ribosomal Database Project 501 II (Center for Microbial Ecology, Michigan State University, 502 http://wdcm.nig.ac.jp/RDP/html/analyses.html). Potential chimeras were eliminated 503 before phylogenetic trees were constructed. The mcrA sequences were then edited 504 in the BioEdit v7.0.5 program (Hall, 1999), translated into amino acid sequences, and 505 aligned using ClustalX (Larkin et al., 2007). Sequence data was analysed with the 506 MEGA4.0.2 program (Tamura et al., 2007). The phylogenetic trees were calculated 507 by the neighbour-joining analysis. The robustness of inferred topology was tested by 508 boostrap resampling (1000). 
509 Rarefaction curves were calculated for each mcrA clone library using the RarFac

510 program (http://www.icbm.de/pmbio/), and we used a 97\% similarity level to define

511 the groups of sequences. Libraries' coverage was calculated using the following 512 formula: $C=\left[1-\left(n_{1} / N\right)\right]^{*} 100$, where $n_{1}$ is the number of unique OTUs, and $N$ is number

513 of clones in the library (Singleton et al., 2001).

514

\section{Nucleotide sequence accession numbers.}

516 The sequence data reported here will appear in GenBank nucleotide sequence

517 databases under the accession no. HM004960 to HM005070 for mcrA genes and 518 HM004950 to HM004959 for 16S rRNA gene DGGE band sequences. Sequences 519 obtained from enrichments are no. HM004946 to HM004949.

520

\section{Acknowledgements.}

522 We would like to thank Josée Sarrazin, the chief scientist of the MEDECO cruise, the 523 ROV team, the officers and crew of the RV Pourquoi Pas? as well as the shipboard 524 scientific community for their help at sea. This work was funded by the HERMES 525 project Contract No: GOCE-CT-2005-511234-1, the ANR Deep Oases, and NERC, 526 UK (NE/F018983/1).

\section{REFERENCES}

529 Altschul, S.F., Gish, W., Miller, W., Myers, EW, and Lipman D.J. (1990) Basic local 530 alignment search tool. J Mol Biol 215: 403-410.

532 Aloisi, G., Pierre, C., Rouchy, J.-M., Foucher, J.-P., and Woodside, J. (2000) 533 Methane-related authigenic carbonates of eastern Mediterranean Sea mud 534 volcanoes and their possible relation to gas hydrate destabilisation. Earth Planet Sci 535 Lett 184:321-338.

537 Balch, W.E., and Wolfe, R.S. (1976) New approach to the cultivation of 538 methanogenic bacteria: 2-mercaptoethanesulfonic acid (HS-CoM)-dependent growth 539 of Methanobacterium ruminatium in a pressurized atmosphere. Appl Environ 540 Microbiol 32: 781-791. 
542 Benlloch, S., López-López, A., Casamayor, E.O., Ovreas, L., Goddard, V., Daee F.L., 543 et al. (2002) Prokaryotic genetic diversity throughout the salinity gradient of a coastal 544 solar saltern. Environ Microbiol 4: 349-360.

545

546 Boetius, A., Ravenschlag, K., Schubert, C.J., Rickert, D., Widdel, F., Gieske, A., et al. 547 (2000) A marine microbial consortium apparently mediating anaerobic oxidation of 548 methane. Nature 407: 623-626.

550 Brandt, K.K., Vester, F., Jensen, A.N., and Ingvorsen, K. (2001) Sulfate reduction 551 dynamics and enumeration of sulfate-reducing bacteria in hypersaline sediments of 552 the Great Salt Lake (Utah, USA). Microb Ecol 41:1-11.

554 Casamayor, E.O., Schäfer, H., Baneras, L., Salio, C.P., and Muyzer, G. (2000) 555 Identification of and Spatio-Temporal Differences between Microbial Assemblages 556 from Two Neighboring Sulfurous Lakes: Comparison by Microscopy and Denaturing 557 Gradient Gel Electrophoresis. Appl Environ Microbiol 66: 499-508.

558

559 Cetecioglu, Z., Ince, B.K., Kolukirik, M., and Ince, O. (2009) Biogeographical 560 distribution and diversity of bacterial and archaeal communities within highly polluted 561 anoxic marine sediments from the marmara sea. Marine Pollution Bulletin 58: 384562395.

563

564 Chaduteau, C. (2008) Origin and circulation of fluids in sediments of margins, 565 Contribution of Helium and methane to the comprehension of the processes, Study of 566 two zones. PhD thesis. Université de Bretagne Occidentale, France. p.121.

568 Charlou, J.L., Donval, J.P., Zitter, T., Roy, N., Jean-Baptiste, P., Foucher, J.P., et al. 569 (2003) Evidence of methane venting and geochemistry of brines on mud volcanoes 570 of the eastern Mediterranean Sea. Deep-sea research Part I 50: 941-958.

572 D'Hondt, S., Jørgensen, B.B., Miller, D.J., Batzke, A., Blake, R., Cragg, B.A., et al. 573 (2004) Distributions of Microbial Activities in Deep Subseafloor Sediments. Science 574 306: 2216-2221. 
576 Daffonchio, D., Borin, S., Brusa, T., Brusetti, L., van der Wielen, P.W.J.J., Bolhuis,

577 H., et al. (2006) Stratified prokaryote network in the oxic-anoxic transition of a deep-

578 sea halocline. Nature 440: 203-207.

579

580 Dhillon, A., Lever, M., Llyod, K.G., Albert, D.B., Sogin, M.L., and Teske, A. (2005)

581 Methanogen diversity evidenced by molecular characterization of methyl coenzyme

$582 M$ reductase A (mcrA) genes in hydrothermal sediments of the Guyamas basin. Appl

583 Environ Microbiol 71: 4592-4601.

584

585 Dimitrov, L.I. (2003) Mud volcanoes-a significant source of atmospheric methane.

586 Geo-Marine Letters 23: 155-161.

587

588 Dolfing, J., Larter, S.R., and Head, I.M. (2008) Thermodynamic constraints on 589 methanogenic crude oil biodegradation. ISME J 2: 442-452.

590

591 Fang, J., Shizuka, A., Kato, C., and Schouten, S. (2006) Microbial diversity of cold592 seep sediments in Sagami Bay, Japan, as determined by 16S rRNA gene and lipid analysis. FEMS Microbiol Ecol 57: 429-441.

594

595

Feseker, T., Dählmann, A., Foucher, J.-P., and Harmegnies, F. (2009) In-situ 596 sediment temperature measurements and geochemical porewater data suggest 597 highly dynamic fluid flow at Isis mud volcano, eastern Mediterranean Sea. Mar Geol 598 261: 128-137.

599

600 Garcia, J.-L., Patel, B.K.C., and Ollivier, B. (2000) Taxonomic, phylogenetic, and 601 ecological diversity of methanogenic Archaea. Anaerobe 6: 205-226.

602

603 Glissmann, K., Chin, K.-J., Casper, P., and Conrad, R. (2004) Methanogenic 604 Pathway and Archaeal Community Structure in the Sediment of Eutrophic Lake 605 Dagow: Effect of Temperature. Microb Ecol 48: 389-399.

606

607 Grabowski, A., Nercessian, O., Fayolle, F., Blanchet, D., and Jeanthon, C. (2005) 608 Microbial diversity in production waters of a low-temperature biodegraded oil 609 reservoir. FEMS Microbiol Ecol 54: 427-443. 
611 Haese, R.R., Hensen, C., and de Lange, G.J. (2006) Pore water geochemistry of eastern Mediterranean mud volcanoes: Implications for fluid transport and fluid origin.

613 Mar Geol 225: 191 - 208.

614

615 Hales, B.A., Edwards, C., Titchie, D.A., Hall, G., Pickup, R.W., and Sauders, J.R. 616 (1996) Isolation and identification of methanogen-specific DNA from blanket bog peat 617 by PCR amplification and sequence analysis. Appl Environ Microbiol 62.

Hall, T.A. (1999) BioEdit: a user-friendly biological sequence alignment editor and analysis program for Windows 95/98/NT. Nucleic Acids Symp Ser 41: 95-98.

Heijs, S.K., Laverman, A.M., Forney, L.J., Hardoim, P.R., and van Elsas, J.D. (2008)

623 Comparison of deep-sea sediment microbial communities in the Eastern 624 Mediterranean. FEMS Microbiol Ecol 64: 362-377.

Holmer, M., and Kristensen, E. (1994) Coexistence of sulfate reduction and methane production in an organic-rich sediment. Mar Ecol Prog Ser 107: 177-184. (2004) Characterization of C1-metabolizing prokaryotic communities in methane seep habitats at the Kuroshima Knoll, southern Ryukyu Arc, by analyzing pmoA, mmoX, mxaF, mcrA, and 16S rRNA genes. Appl Environ Microbiol 70: 7445-7455.

634 Janse, I., Bok, J., and Zwart, G. (2004) A simple remedy against artifactual double bands in denaturing gradient gel electrophoresis. J Microbiol Methods 57: 279- 281.

637 Jiang, H, Dong, H., Yu, B., Ye, Q., Shen, J., Rowe, H., and Zhang, C. (2008) 638 Dominance of putative marine benthic Archaea in Qinghai Lake, north-western 639 China. Environ Microbiol 10: 2355-2367.

641 Joye, S.B., Connell, T.L., Miller, L.G., Oremland, R.S., and Jellison, R.S. (1999) 642 Oxidation of ammonia and methane in an alkaline, saline lake. Limnol Oceanogr 44: 643 178-188. 
645 Joye, S.B., Samarkin, V.A., Orcutt, B.N., MacDonald, I.R., Hinrichs, K.-U., Elvert, M., 646 et al. (2009) Metabolic variability in seafloor brines revealed by carbon and sulphur 647 dynamics. Nature Geoscience 2: 349-354.

648

649 Kelley, C.A., Prufert-Bebout, L.E., and Bebout, B.M. (2006) Changes in carbon 650 cycling ascertained by stable isotopic analyses in a hypersaline microbial mat. 651 Journal of geophysical research 111: doi:10.1029/2006JG000212.

652

653 Kendall, M.M., and Boone, D.R. (2006) Cultivation of methanogens from shallow 654 marine sediments at Hydrate ridge, Oregon. Archaea 2: 1-8.

Kendall, M.M., Wardlaw, G.D., Tang, C.F., Bonin, A.S., Liu, Y., and Valentine, D.L. 657 (2007) Diversity of Archaea in marine sediments from Skan Bay, Alaska, including 658 cultivated methanogens, and description of Methanogenium boonei sp. nov. Appl 659 Environ Microbiol 73: 407-414.

661 Kleikemper, J., Pombo, S.A., Schroth, M.H., Sigler, W.V., Pesaro, M., and Zeyer, J. 662 (2005) Activity and diversity of methanogens in a petroleum hydrocarbon663 contaminated aquifer. Appl Environ Microbiol 71: 149-158.

664

665 Knittel, K., Lösekann, T., Boetius, A., Kort, R., and Amann, R. (2005) Diversity and 666 distribution of methanotrophic Archaea at cold seeps. Appl Environ Microbiol 71: 467667479.

Knittel, K., and Boetius, A. (2009) Anaerobic Oxidation of Methane: Progress with an Unknown Process. Annu Rev Microbiol 63: 311-334.

672 Kvenvolden, K.A. (1988) Methane hydrates-A major reservoir of carbon in the 673 shallow geosphere ? Chem Geol 71: 41-51.

674

675 Larkin, M.A., Blackshields, G., Brown, N.P., Chenna, R., McGettigan, P.A., 676 McWilliam, H., et al. (2007) Clustal W and Clustal X version 2.0. Bioinformatics 23: 677 2947-2948. 
679 Lloyd, K.G., Lapham, L., and Teske, A. (2006) An anaerobic methane-oxidizing 680 community of ANME-1b Archaea in hypersaline Gulf of Mexico sediments. Appl 681 Environ Microbiol 72: 7218-7230.

682

683 Lösekann, T., Knittel, K., Nadalig, T., Fuchs, B., Niemann, H., Boetius, A., and 684 Amann, R. (2007) Diversity and abundance of aerobic and anaerobic methane 685 oxidizers at the Haakon Mosby Mud Volcano, Barents Sea. Appl Environ Microbiol 686 73: 3348-3362.

687

688 Lozupone, C.A., and Knight, R. (2007) Global patterns in bacterial diversity. Proc Natl 689 Acad Sci U S A 104: 11436-11440.

690

691 Lyimo, T.J., Pol, A., Op den Camp, H.J.M., Harhangi, H.R., and Vogels, G.D. (2000) 692 Methanosarcina semesiae sp. nov., a dimethylsulfide-utilizing methanogen from 693 mangrove sediment. Int J Syst Evol Microbiol 50: 171-178.

694

695 Lyimo, T.J., Pol, A., Jetten, M.S.M., and Op den Camp, H.J.M. (2009) Diversity of 696 methanogenic archaea in a mangrove sediment and isolation of a new 697 Methanococcoides strain. FEMS Microbiol Ecol 291: 247-253.

698

699 McGenity, T.J. (2010) Methanogens and Methanogenesis in Hypersaline 700 Environments. In Handbook of Hydrocarbon and Lipid Microbiology, Part 8. Timmis, 701 K.N. (ed). Springer-Verlag Berlin and Heidelberg, pp. 665-680.

702

703 Mikucki, J.A., Liu, Y., Delwiche, M., Colwell, F.S., and Boone, D.R. (2003) Isolation of 704 a methanogen from deep marine sediments that contain methane hydrates, and 705 description of Methanoculleus submarinus sp. nov. Appl Environ Microbiol 69: 3311 7063316.

707

708 Milkov, A. (2000) Worldwide distribution of submarine mud volcanoes and associated 709 gas hydrates. Mar Geol 167: 29-42. 
711 Mills, H.J., Hodges, C., Wilson, K., MacDonald, I.R., and Sobecky, P.A. (2003) 712 Microbial diversity in sediments associated with surface-breaching gas hydrate 713 mounds in the Gulf of Mexico. FEMS Microbiol Ecol 46: 39-52.

714

715 Mills, H.J., Martinez, R.J., Story, S., and Sobecky, P.A. (2004) Identification of 716 members of the metabolically active microbial populations associated with Beggiatoa 717 species mat communities form Gulf of Mexico cold-seep sediments. Appl Environ 718 Microbiol 70: 5447-5458.

719

720 Newberry, C.J., Webster, G., Cragg, B.A., Parkes, R.J., Weightman, A.J., and Fry, 721 J.C. (2004) Diversity of prokaryotes and methanogenesis in deep subsurface 722 sediments from the Nankai Trough, Ocean Drilling Program Leg 190. Environ 723 Microbiol 6: 274-287.

724

725

Niederberger, T.D., Perreault, N.N., Tille, S., Lollar, B.S., Lacrampe-Couloume, G., Andersen, D. et al. (2010) Microbial characterization of a subzero, hypersaline methane seep in the Canadian High Arctic. ISME J 4: 1326-1339.

728

729 Niemann, H., Duarte, J., Hensen, C., Omoregie, E., Magalhaes, V.H., Elvert, M., et 730 al. (2006) Microbial methane turnover at mud volcanoes of the Gulf of Cadiz. 731 Geochim Cosmochim Acta 70: 5336-5355.

733 Olu-Le Roy, K., Sibuet, M., Fiala-Médioni, A., Gofas, S., Salas, C., Mariotti, A., et al. 734 (2004) Cold seep communities in the deep eastern Mediterranean Sea: composition, 735 symbiosis and spatial distribution on mud volcanoes. Deep-sea research Part I 51: 736 1915-1936.

738 Omoregie, E.O., Mastalerz, V., de Lange, G., Straub, K.L., Kappler, A., Røy, H., et al. 739 (2008) Biogeochemistry and Community Composition of Iron- and Sulfur-Precipitating 740 Microbial Mats at the Chefren Mud Volcano (Nile Deep Sea Fan, Eastern 741 Mediterranean). Appl Environ Microbiol 74: 3198-3215. 
743 Oremland, R.S., Marsh, L.M., and Polcin, S. (1982) Methane production and

744 simultaneous sulphate reduction in anoxic, salt marsh sediments. Nature 296: 143745145.

746

747 Oren, A. (1999) Bioenergetic Aspects of Halophilism. Microbiology and Molecular 748 Biology Reviews 63: 334-348.

749

750 Ovreas, L., Forney, L., Daae, F.L., and Torsvik, V. (1997) Distribution of 751 bacterioplankton in meromictic Lake Saelenvannet, as determined by denaturing 752 gradient gel electrophoresis of PCR-amplified gene fragmetns coding for 16S rRNA. 753 Appl Environ Microbiol 63: 3367-3373.

754

755

Parkes, R.J., Cragg, B.A., and Wellsbury, P. (2000) Recent studies on bacterial 756 populations and processes in subseafloor sediments: A review. Hydrogeology journal 757 8: 11-28.

758

759

Parkes, R.J., Webster, G., Cragg, B.A., Weightman, A.J., Newberry, C.J., Ferdelman, 760 T.G., et al. (2005) Deep sub-seafloor prokaryotes stimulated at interfaces aver geological times. Nature 436: 390-394.

762

763

Parkes, R.J., Cragg, B.A., Banning, N., Brock, F., Webster, G., Fry, J.C., et al. (2007)

764 Biogeochemistry and biodiversity of methane cycling in subsurface marine sediments 765 (Skagerrak, Denmark). Environ Microbiol 9: 1146-1161.

766

767

Perreault, N.N., Andersen, D.T., Pollard, W.H., Greer, C.W., and Whyte, L.G. (2007) 768 Characterization of the Prokaryotic Diversity in Cold Saline Perennial Springs of the 769 Canadian High Arctic. Appl Environ Microbiol 73: 1532-1543.

770

771 Purdy, K.J., Munson, M.A., Cresswell-Maynard, T., Nedwell, D.B., and Embley, T.M. 772 (2003) Use of 16S rRNA-targeted oligonucleotide probes to investigate function and 773 phylogeny of sulphate-reducing bacteria and methanogenic archaea in a UK estuary. 774 FEMS Microbiol Ecol 44: 361-371. 
776 Roussel, E.G., Sauvadet, A.-L., Allard, J., Chaduteau, C., Richard, P., Cambon 777 Bonavita, M.-A., and Chaumillon, E. (2009) Archaeal Methane Cycling Communities 778 Associated with Gassy Subsurface Sediments of Marennes-Oléron Bay (France). 779 Geomicrobiol J 26: 31-43.

Sarradin, P.-M., and Caprais, J.C. (1996) Analysis of dissolved gases by headspace sampling, gas chromatography with columns and detectors commutation. Preliminary results. Analytical Communications 33: 371-373.

Schulz, S., Matsuyama, H., and Conrad, R. (1997) Temperature dependence of 786 methane production from different precursors in a profundal sediment (Lake Constance). FEMS Microbiol Ecol 22: 207-213. Methanobacterium aarhusense sp nov., a novel methanogen isolated from a marine sediment (Aarhus Bay, Denmark). Int J Syst Evol Microbiol 54: 759-763.

792

793 Singh, N., Kendall, M.M., Liu, Y., and Boone, D.R. (2005) Isolation and 794 characterization of methylotrophic methanogens from anoxic marine sediments in 795 Skan Bay, Alaska: description of Methanococcoides alaskense sp. nov., and 796 emended description of Methanosacina baltica. Int J Syst Evol Microbiol 55: 25317972538.

799 Singleton, D.R., Furlong, M.A., Rathbun, S.L., and Whitman, W.B. (2001) 800 Quantitative Comparisons of 16S rRNA Gene Sequence Libraries from 801 Environmental Samples. Appl Environ Microbiol 67: 4374-4376.

803 Sorensen, K.B., Canfield, D.E., Teske, A.P., and Oren, A. (2005) Community 804 Composition of a Hypersaline Endoevaporitic Microbial Mat. Appl Environ Microbiol 805 70: 7352-7365.

807 Sowers, K.R., and Ferry, J.G. (1983) Isolation and characterization of a 808 methylotrophic marine methanogen, Methanococcoides methylutens gen. nov., sp. nov. Appl Environ Microbiol 45: 684-690. 
811 Sowers, K.R., Baron, S.F., and Ferry, J.G. (1984) Methanosarcina acetivorans sp.

812 nov., an acetoclastic methane-producing bacterium isolated from marine sediments.

813 Appl Environ Microbiol 47: 971-978.

814

815 Tamura, K., Dudley, J., Nei, M., and Kumar, S. (2007) MEGA4: Molecular 816 Evolutionary Genetics Analysis (MEGA) Software Version 4.0. Mol Biol Evol 24: $817: 1596-1599$.

818

819 van der Wielen, P.W.J.J., Bolhuis, H., Borin, S., Daffonchio, D., Corselli, C., Giuliano, 820 L., et al. (2005) The Enigma of Prokaryotic Life in Deep Hypersaline Anoxic Basins. 821 Science 307: 121-123.

822

823 von Klein, D., Arab, H., Völker, H., and Thomm, M. (2002) Methanosarcina baltica, 824 sp. nov., a novel methanogen isolated from the Gotland Deep of the Baltic sea. 825 Extremophiles 6: 103-110.

826

827 Vetriani, C., Jannasch, H.W., MacGregor, B.J., Stahl, D.A., and Reysenbach, A.-L. 828 (1999) Population structure and phylogenetic characterization of marine bentic 829 Archaea in deep-sea sediments. Appl Environ Microbiol 65: 4375-4384.

830

831 Webster, G., Newberry, C.J., Fry, J.C., and Weightman, A.J. (2003) Assessment of 832 bacterial community structure in the deep sub-seafloor biosphere by $16 \mathrm{~S}$ rDNA833 based techniques: a cautionary tale. Journal of microbiological methods 55: 155834164.

836 Webster, G., Blazejak, A., Cragg, B.A., Schippers, A., Sass, H., Rinna, J., et al. 837 (2008) Subsurface microbiology and biogeochemistry of a deep, cold-water 838 carbonate mound from the Porcupine Seabight (IODP Expedition 307). Environ 839 Microbiol.

841 Wegener, G., Niemann, H., Elvert, M., Hinrichs, K.-U., and Boetius, A. (2008) 842 Assimilation of methane and inorganic carbon by microbial communities mediating 843 the anaerobic oxidation of methane. Environ Microbiol 10:2287-2298. 
845 Whiticar, M.J., Faber, E., and Schoell, M. (1986) Biogenic methane formation in 846 marine and freshwater environments: CO2 reduction vs acetate fermentation-Isotope 847 evidence. Geochim Cosmochim Acta 50:693-709.

848

849 Yakimov, M.M., Giuliano, L., Cappello, S., Denaro, R., and Golyshin, P.N. (2007a)

850 Microbial Community of a Hydrothermal Mud Vent Underneath the Deep-Sea Anoxic 851 Brine Lake Urania (Eastern Mediterranean). Orig Life Evol Biosph 37: 177-188.

852

853 Yakimov, M.M., La Cono, V., Denaro, R., D’Auria, G., Decembrini, F., Timmis, K.N. et 854 al. (2007b) Primary producing prokaryotic communities of brine, interface and 855 seawater above the halocline of deep anoxic lake L'Atalante, Eastern Mediterranean 856 Sea. ISME J 1:743-755.

857

858 Zengler, K., Richnow, H.H., Rossello-Mora, R., Michaelis, W., and Widdel, F. (1999) 859 Methane formation from long-chain alkanes by anaerobic microorganisms. Nature 860 401: 266-269.

861

862 Zepp Falz, K., Holliger, C., Grosskopf, R., Liesack, W., Nozhevnikova, A.N., Müller, 863 B., Wehrli, B., and Hahn, D. (1999) Vertical Distribution of Methanogens in the Anoxic 864 Sediment of Rotsee (Switzerland). Appl Environ Microbiol 65: 2402-2408.

865

866 Zhilina, T.N., and Zavarzin, G.A. (1990) Extremely halophilic, methylotrophic, 867 anaerobic bacteria. FEMS Microbiol Rev 87: 315-322.

868

869 Zhou, J., Bruns, M.A., and Tiedje, J.M. (1996) DNA recovery from soils of diverse 870 composition. Appl Environ Microbiol 62: 316-322. 


\section{Page 29 of 43}

Wiley-Blackwell and Society for Applied Microbiology

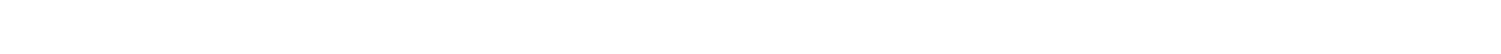

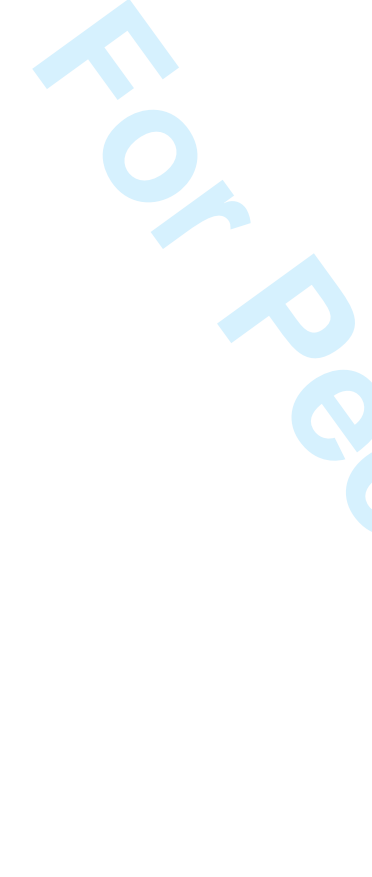

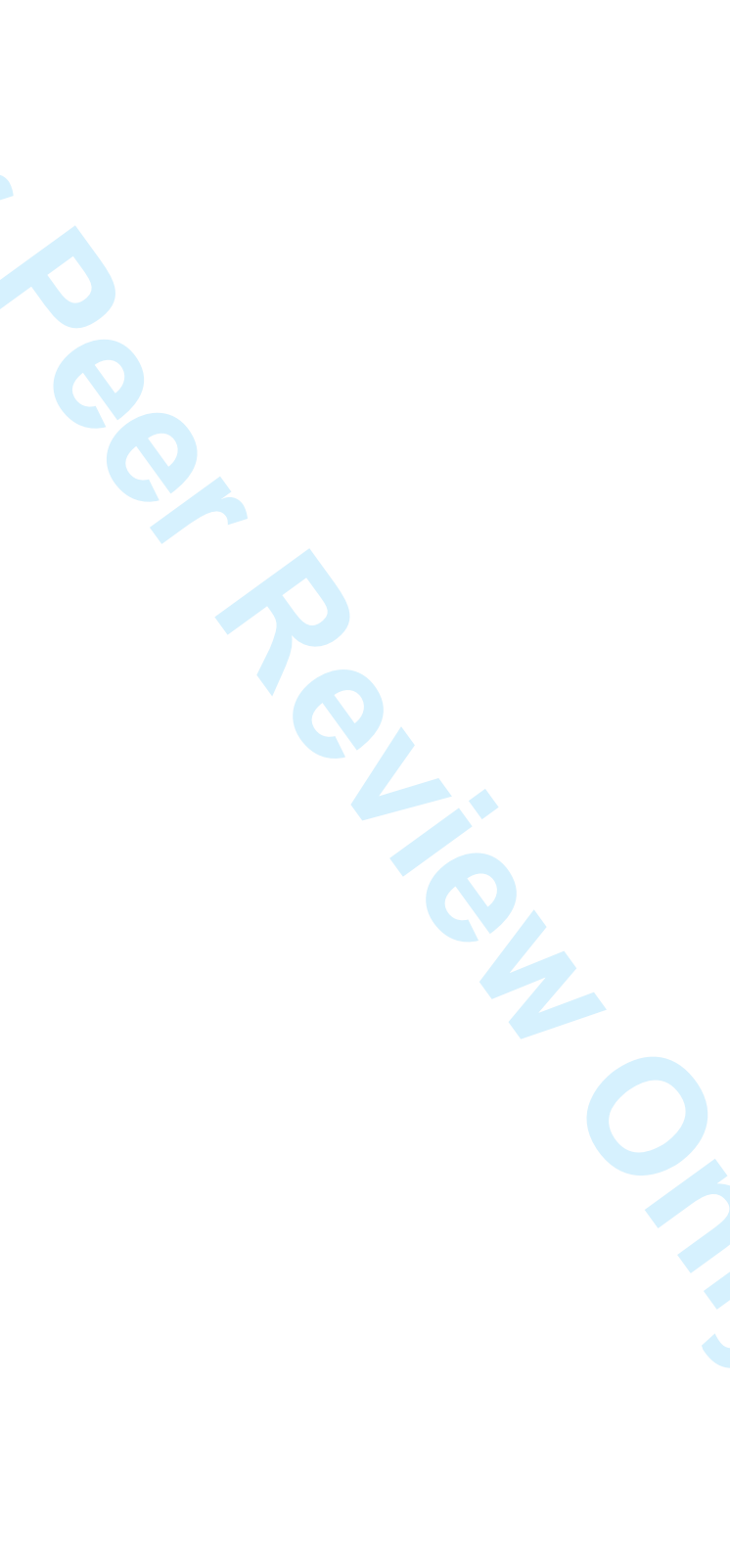

(1)

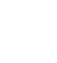

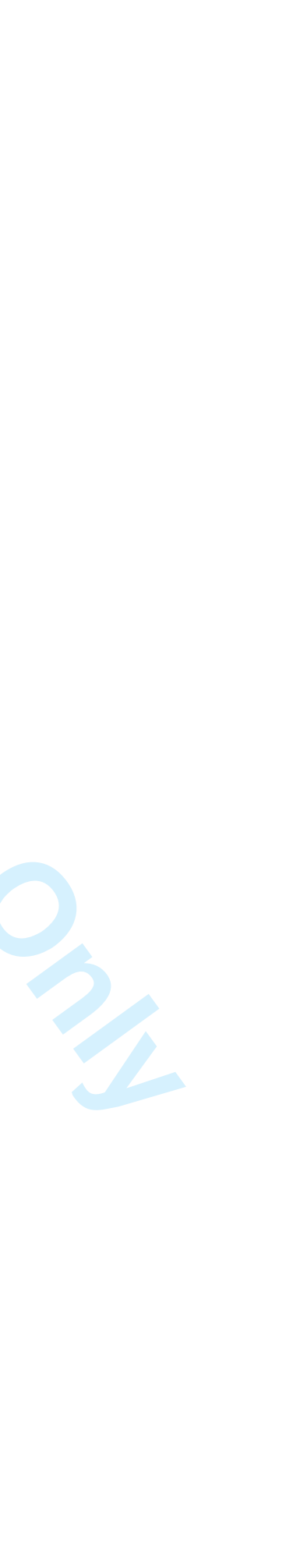

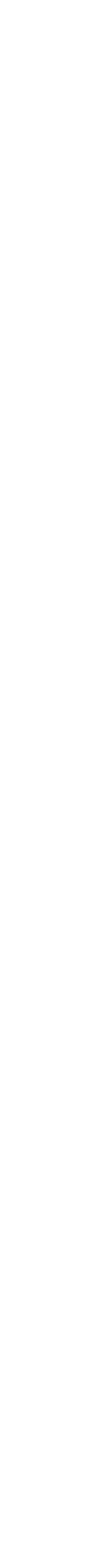




\begin{tabular}{|c|c|c|c|}
\hline Phylogenetic affiliation & DGGE band & Closest uncultured relative (accession number) and origin & $\begin{array}{l}\text { Sequence } \\
\text { identity (\%) }\end{array}$ \\
\hline MBG-D & NapK-dggeB4 (0-20 cmbsf) & $\begin{array}{c}\text { SMI1-GC205-Arc25 (DQ521770) } \\
\text { Hypersaline Sediments, Gulf of Mexico }\end{array}$ & 100 \\
\hline \multirow{6}{*}{ ANME-1 } & NapK-dggeB10 (80-100 cmbsf) & $\begin{array}{l}\text { SMI1-GC205-Arc38 (DQ521781) } \\
\text { Hypersaline Sediments, Gulf of Mexico }\end{array}$ & 98 \\
\hline & NapK-dggeB1 (0-20 cmbsf) & $\begin{array}{l}\text { V.8.ArB20 (AY367348) } \\
\text { Seawater and Sediments of the Cascadia Margin }\end{array}$ & 98 \\
\hline & NapK-dggeB2 (0-20 cmbsf) & $\begin{array}{l}\text { SMI2-GC205-Arc61 (DQ521758) } \\
\text { Hypersaline Sediments, Gulf of Mexico }\end{array}$ & 99 \\
\hline & NapK-dggeB3 (0-20 cmbsf) & $\begin{array}{c}\text { A163B12 (FJ455954) } \\
\text { SMTZ, Santa Barbara Basin, California }\end{array}$ & 97 \\
\hline & NapK-dggeB5 (20-40 cmbsf) & $\begin{array}{l}\text { BA1b1 (AF134382) } \\
\text { Eel River Basin, Northern California }\end{array}$ & 98 \\
\hline & NapK-dggeB6 (20-40 cmbsf) & $\begin{array}{l}\text { V.8.ArB20 (AY367348) } \\
\text { Seawater and Sediments of the Cascadia Margin }\end{array}$ & 96 \\
\hline ANME-2 & NapK-dggeB7 (60-80 cmbsf) & $\begin{array}{c}\text { Kazan-3A-05 (AY592029) } \\
\text { Kazan Mud Volcano, Mediterrenean Sea }\end{array}$ & 98 \\
\hline & NapK-dggeB8 (60-80 cmbsf) & $\begin{array}{l}\text { a149 (FM179915) } \\
\text { Gullfaks and Tommeliten Methane Seeps, Northern North Sea }\end{array}$ & 98 \\
\hline ANME-3 & NapK-dggeB9 (60-80 cmbsf) & $\begin{array}{l}\text { R45_1d_E12 (EU084525) } \\
\text { Sediments from a deep-sea whale-fall in Monterey Canyon }\end{array}$ & 98 \\
\hline
\end{tabular}

Table 1. Closest $16 \mathrm{~S}$ rRNA gene sequences matches to the dominant DGGE excised bands detected by nested PCR-DGGE in the Napoli center sediments, using the NCBI BLASTN search. 


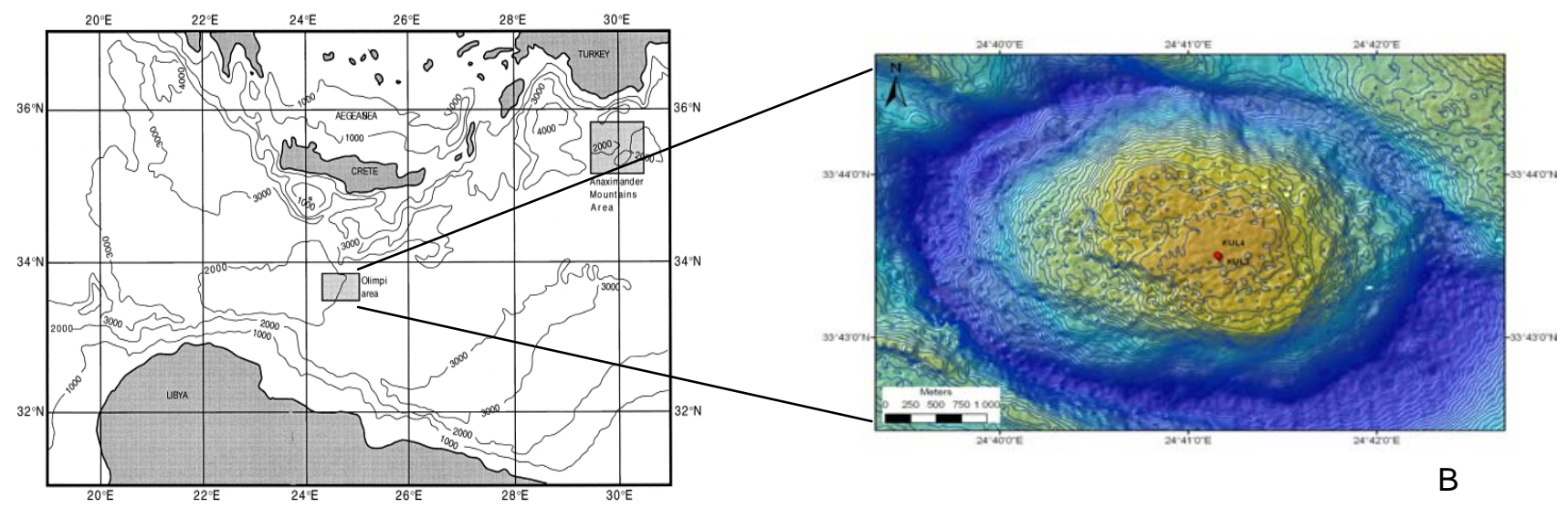

A

Figure 1. A) Location map showing the Olimpi area in the Eastern Mediterranean Sea. From Aloisi et al. (2000). B) Closer view of the Napoli mud volcano and the sampled gravity cores KUL-3, and KUL-4 (Bénédicte Ritt, pers. comm.). 


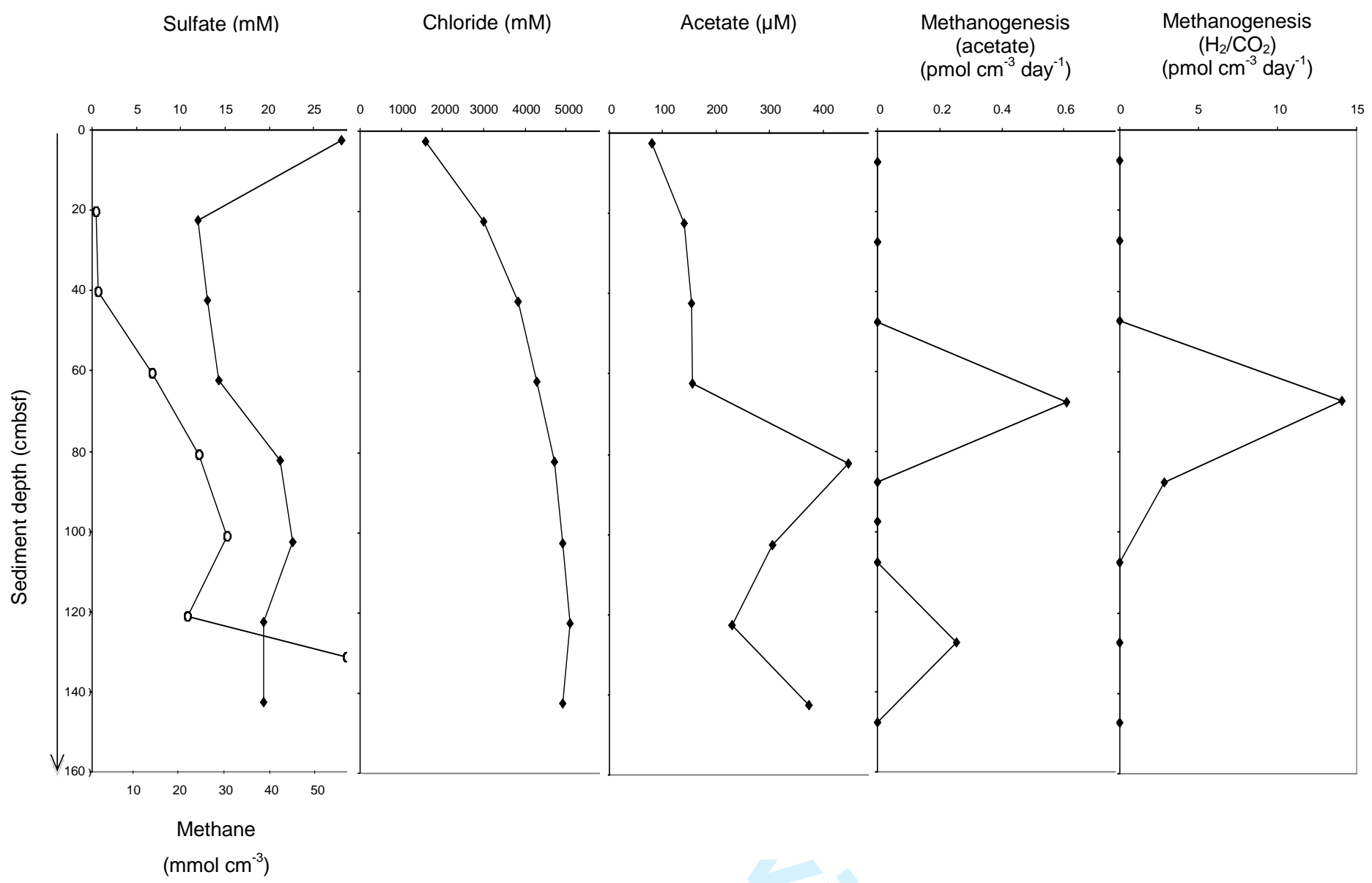

Figure 2. Depth profiles of geochemistry and methanogenic activities in the Napoli mud volcano center sediments. Filled diamonds are sulfate concentrations, and open circles are methane concentrations in $\mathrm{mmol}$ per $\mathrm{cm}^{3}$ of sediment. The scale represents sediment depth below the seafloor. 


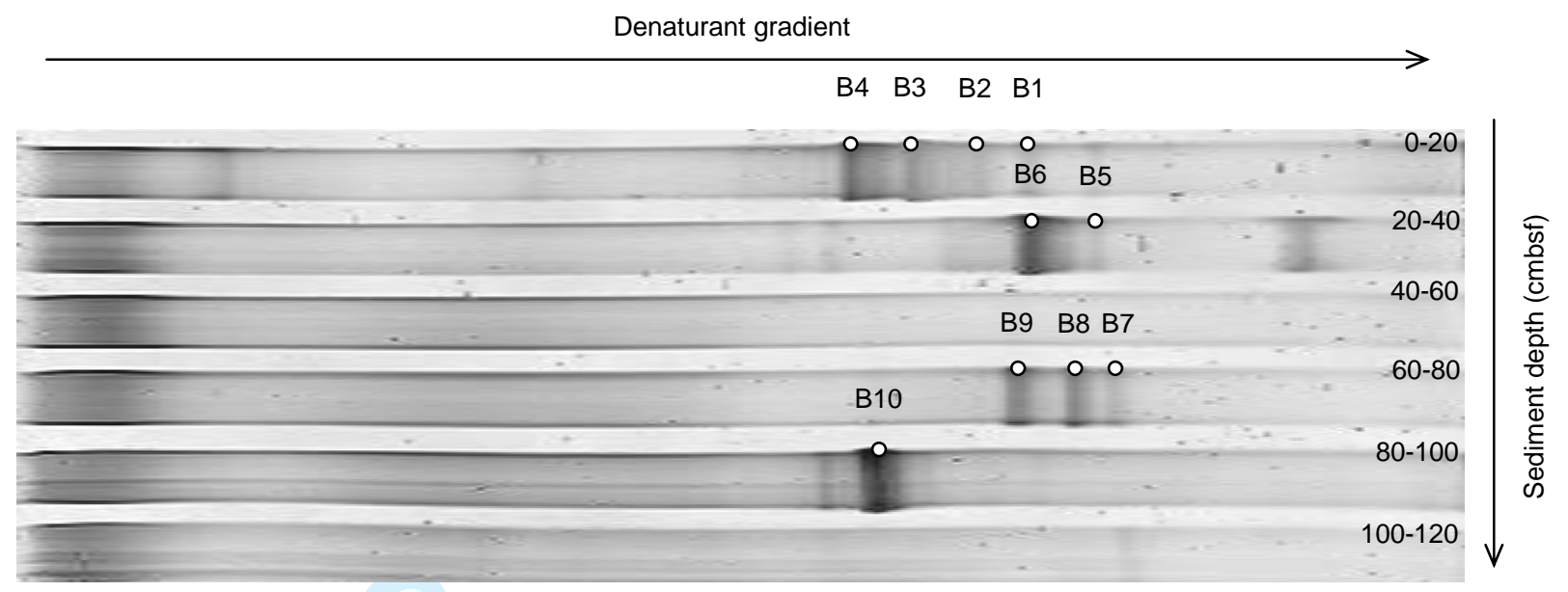

Figure 3. DGGE analysis of archaeal $16 \mathrm{~S}$ rRNA gene sequences from various sediment depths of the Napoli mud volcano. Numbers B1 to B10 (white dots) are bands corresponding to NapK-dggeB1 to NapK-dggeB10, excised from the gel. 
NapK-100 120-mcrB02

Clone GZfos 19C7 (AY714830) Eel River Basin

Clone GZfos_9_28_6 (AY324372) Monterey Canyon

NapK-100_120-mcrG10

NapK-60_80-mcrA06

NapK-40_60-mcrH02

NapK-100_120-mcrF08

NapK-100_120-mcrA08

Clone SMI1-GC205-mcr12 (DQ521864) Hypersaline sediments of the Gulf of Mexico

NapK-40_60-mcrF10

NapK-40_60-mcr

NapK-60_80-mcrc08

Napk-100_120-mcre08

Napk-100_120-mcrG08

- NapK-100_120-mcrH02

NapK-100 120-mcrH12

NapK-100_120-mcrA08 (+3)

NapK-40_60-mcrH05

NapK-100_120-mcre12

NapK-40_60-mcrA04 (+1)

NapK-100_120-mcrG02

NapK-100_120-mcrD12

NapK-40_60-mcrD12

(10)

NapK-40_60-mcrB06

NapK-40_60-mcrC10
NapK-40_60-mcrD08

$-{ }_{\text {NapK-40_60-mcrF04 }}$ NapK-40_-mcros

NapK-60_80-mcrF02

Clone F17_1_30A02 (AY324363) Monterey Canyon

Clone SMI1-GC205-mcr50 (DQ521862) Hypersaline sediments of the Gulf of Mexico

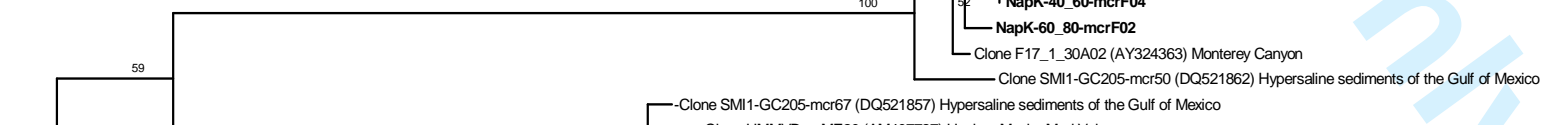
Clone HMMVBeg-ME20 (AM407727) Haakon Mosby Mud Volcano

\section{Clone KM-m-1.19 (AB233460) Methane seep Nankai Trough NapK-40_60-mcrC06}

Clone KM-m-4.10 (AB233466) Methane seep Nankai Trough
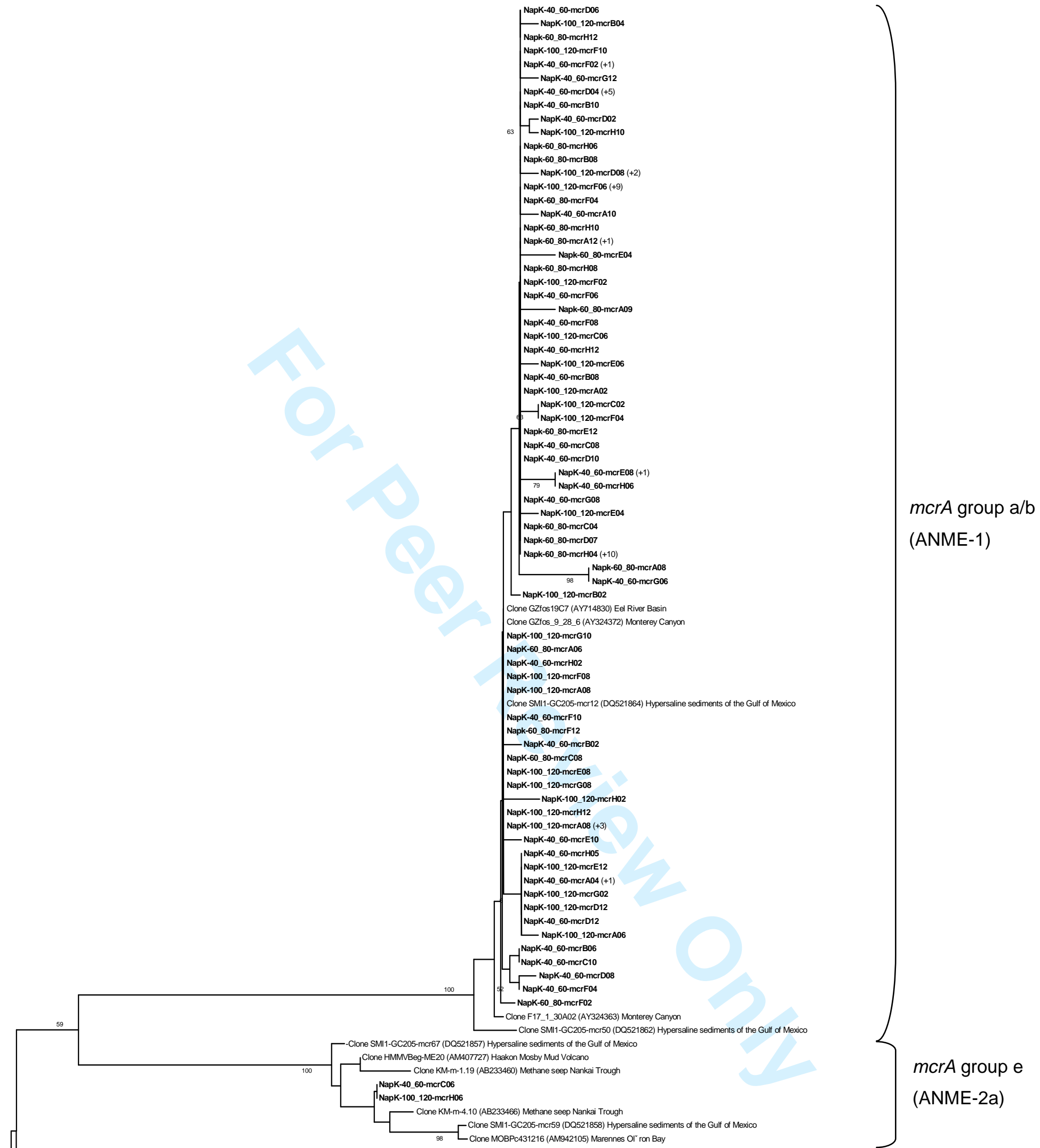
Clone MOBPc431216 (AM942105) Marennes Ol' ron Bay
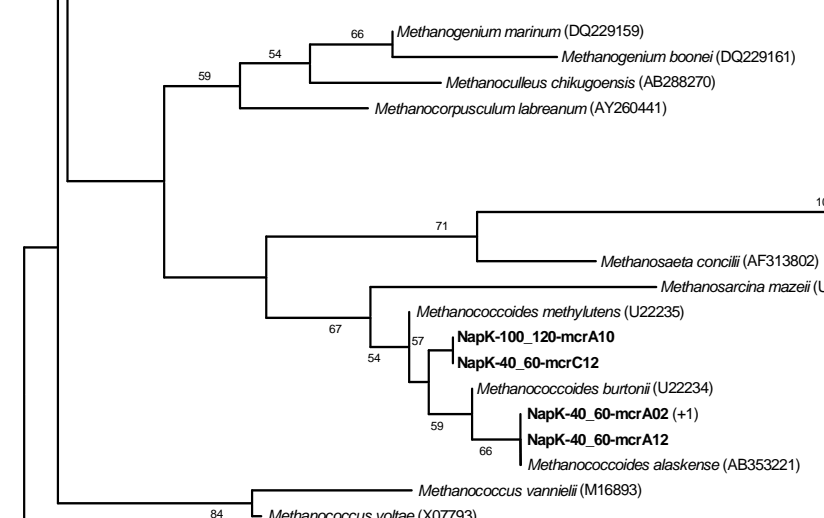

Clone Kuro-mcrA-4.15 (AB176932) Methane seep Kuroshima Knoll

Clone KM-m-4.04 (AB233465) Methane seep Nankai Trough

Clone F17.1-30H02. (AY324365) Monterey Canyon

Clone ODP8-ME1 (AF121099) Methane hydrate Cascadia Margin

LClone AN07BC1_20_11 (AY883179) Kazan mud volcano
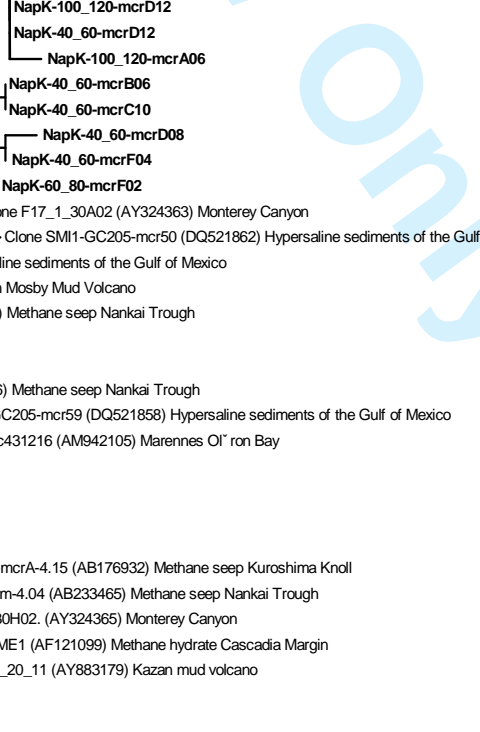
Figure 4. Phylogenetic analysis of MCR amino acid sequences from the center of the Napoli mud volcano sediments based on the neighbour-joining method with approximately 258 amino acid positions. Boostrap values (in percent) are based on 1000 replicates and are indicated at nodes for branches values $\geq 50 \%$ boostrap support. Gene sequences from the Napoli mud volcano sediments are in boldface. Clones with designation beginning NapK-40_60 are from section 40 to $60 \mathrm{cmbsf}$, clones with designation NapK-60_80 are from section 60 to $80 \mathrm{cmbsf}$, and clones with designation NapK-100_120 are from section 100 to $120 \mathrm{cmbsf}$. Numbers in brackets indicate the number of analyzed clones that have more than $97 \%$ sequence identity. 


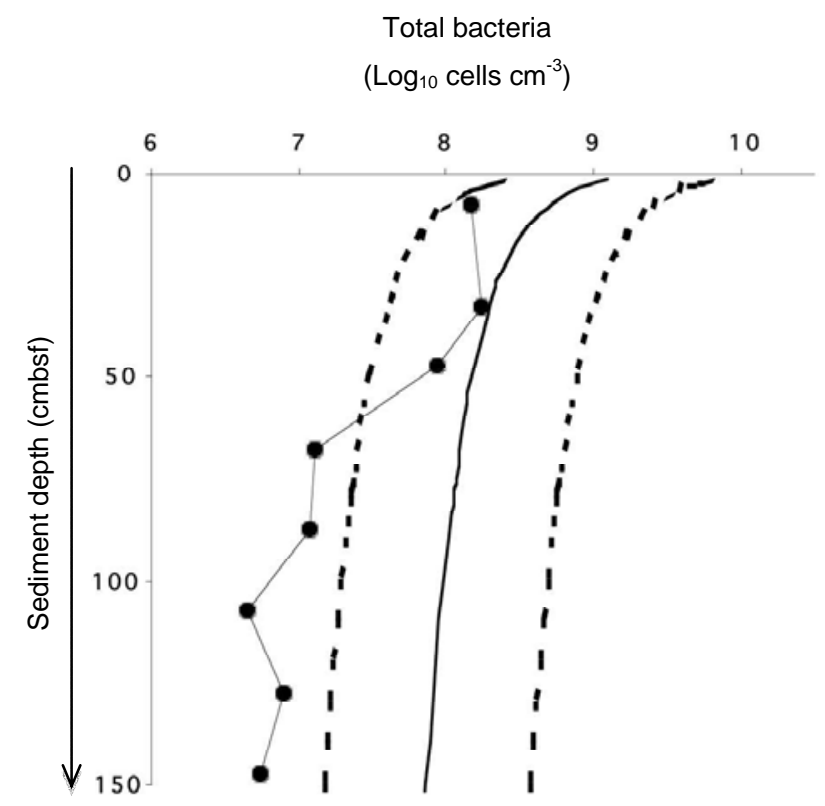

Figure 5. Depth profile of total prokaryotic cells in the Napoli mud volcano center sediments. The black line represents a general regression equation based on total prokaryotic cell counts from diverse marine sediments, with upper and lower prediction limits (95\%) shown by dashed lines, from Parkes et al. (2000). 


\section{SUPPLEMENTARY MATERIAL}

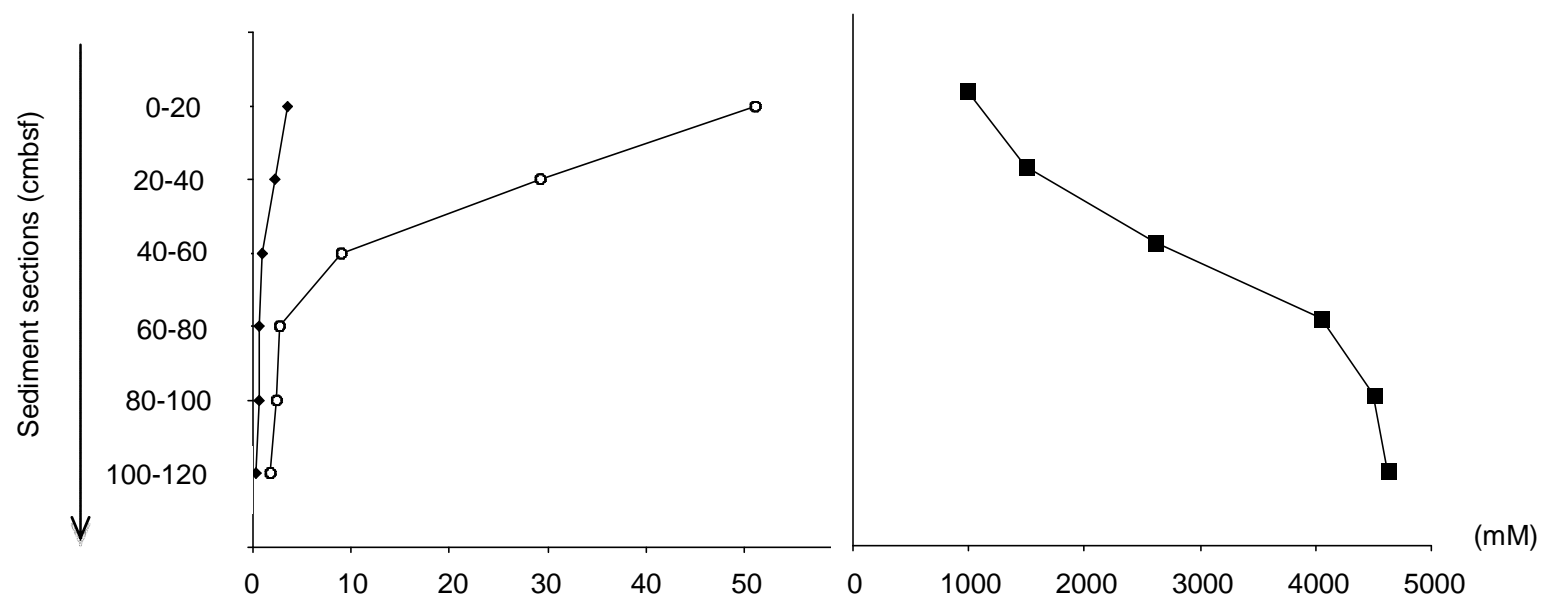

SM1. Depth profiles of the porewater concentrations of $\mathrm{Mg}^{2+}$ (open circles), $\mathrm{Na}^{+}$(filled squares), and $\mathrm{Ca}^{2+}$ (filled diamonds) in the Napoli mud volcano centre sediment sections. 


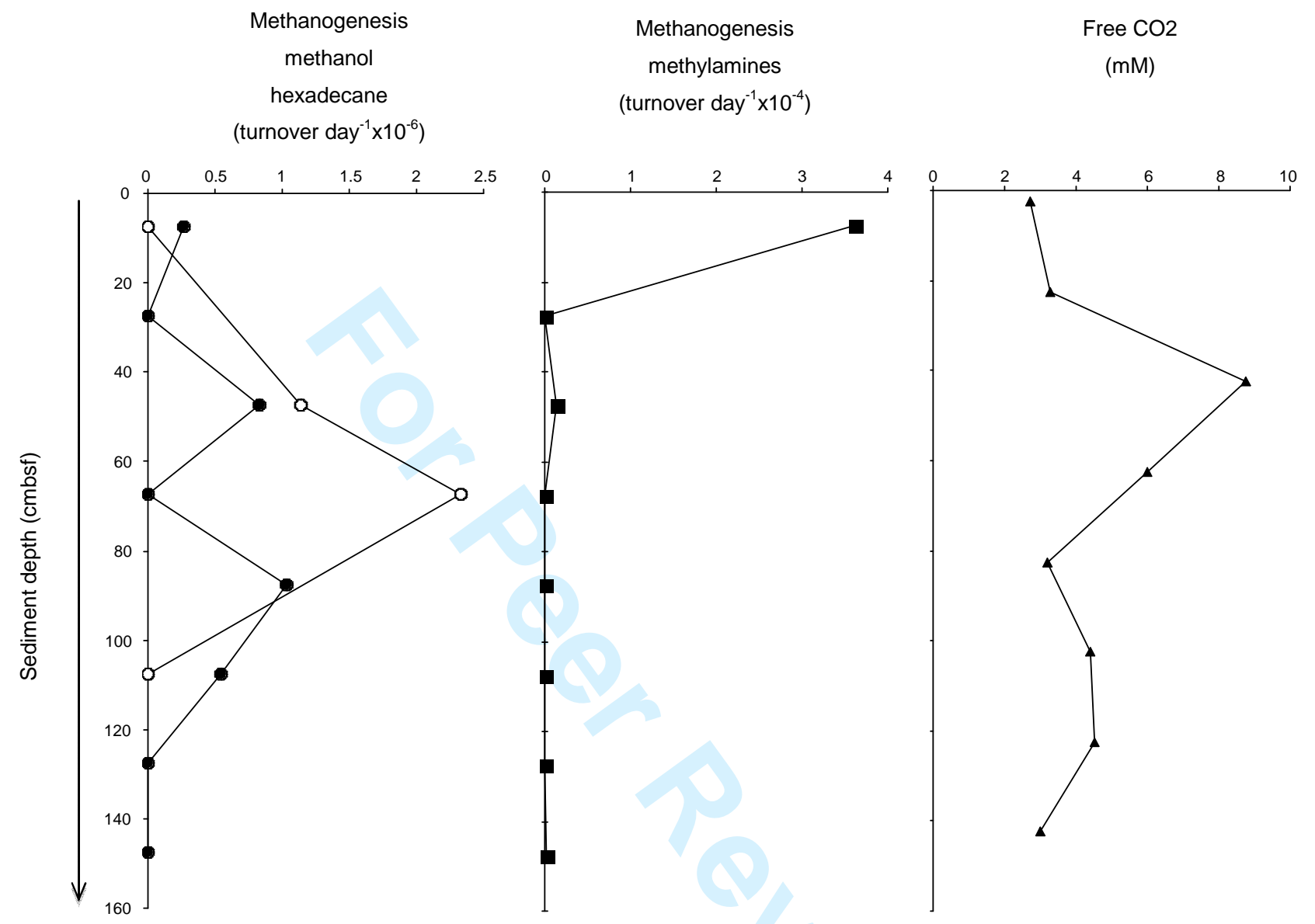

SM2. Depth profiles of methanogenic activities from methylamines, methanol (filled circles) and hexadecane (open circles), and free $\mathrm{CO}_{2}$ in the Napoli mud volcano center sediments. Methanogenic rates are expressed in turnover/day. 


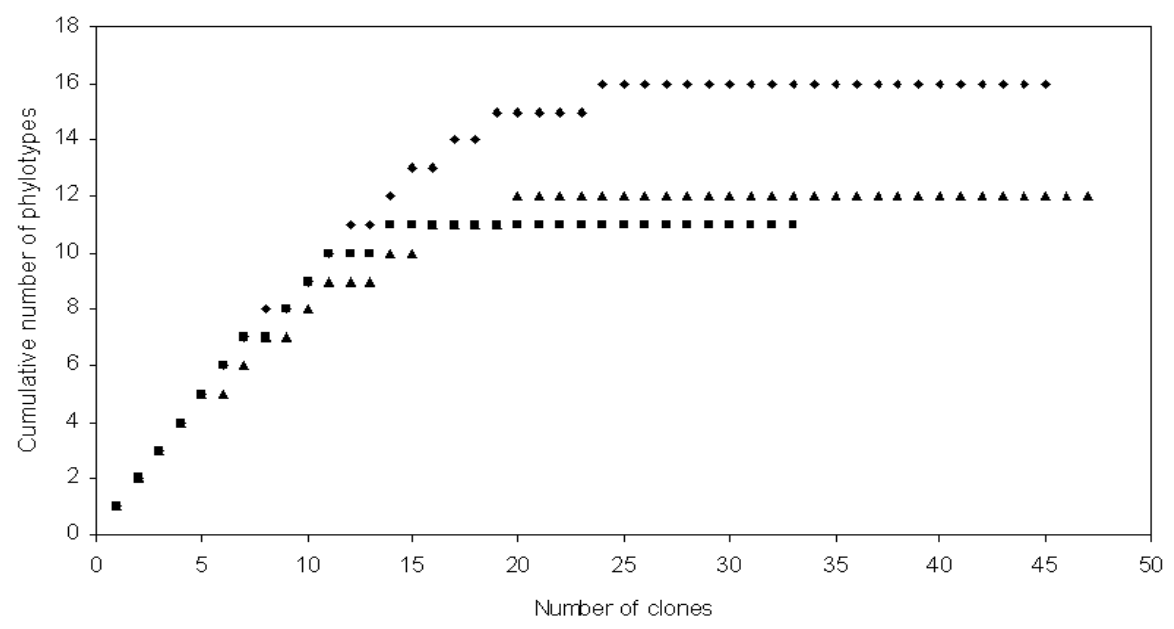

SM3. Rarefaction analysis of the mcrA gene libraries sections $40-60 \mathrm{cmbsf}$ (filled triangles), $60-80$ cmbsf (filled squares), and 100-120 cmbsf (filled diamonds), done using the RarFac program. 


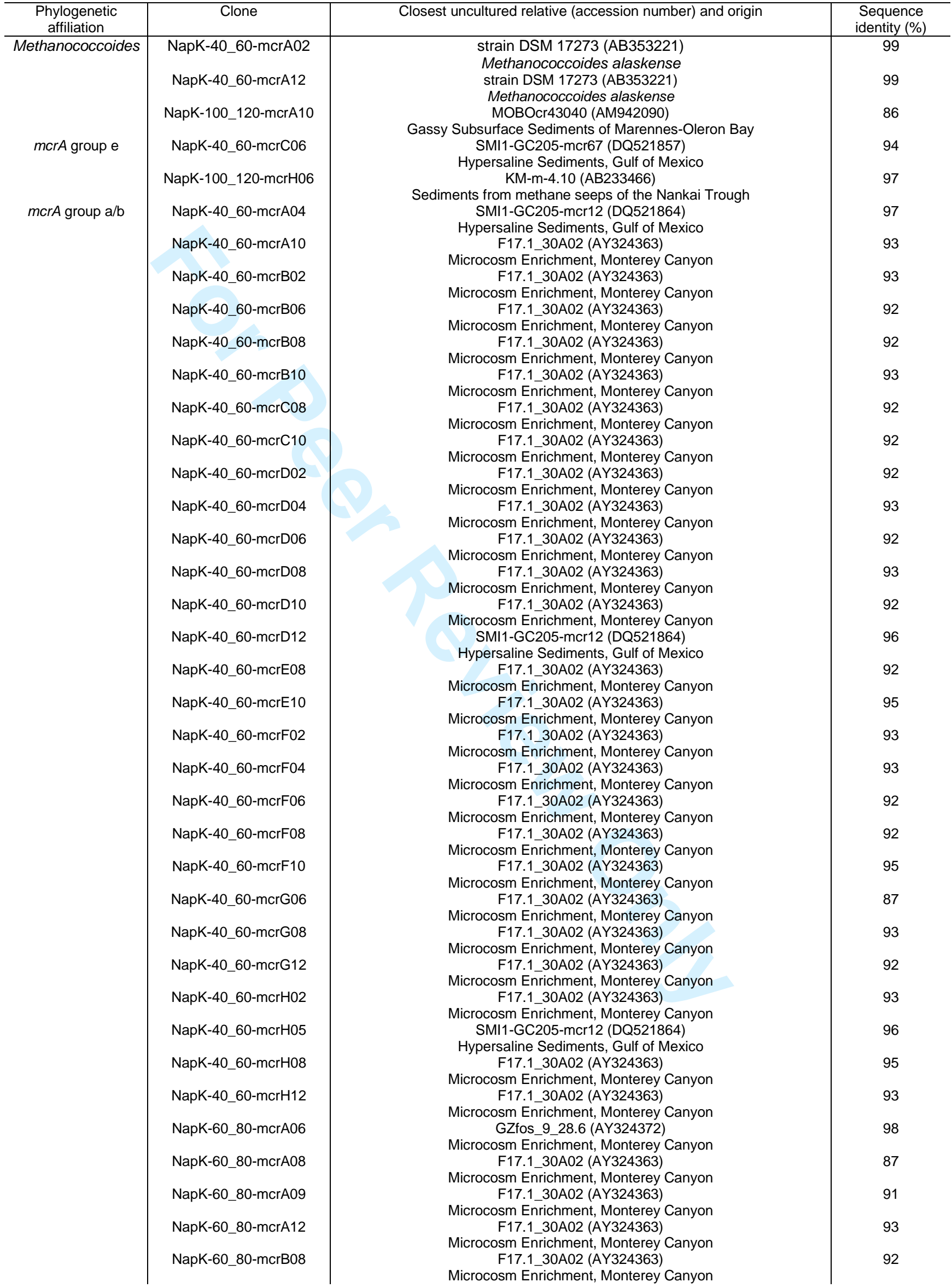


NapK-60_80-mcrC04

NapK-60_80-mcrC08

NapK-60_80-mcrD07

NapK-60_80-mcrE04

NapK-60_80-mcrE12

NapK-60_80-mcrF02

NapK-60_80-mcrF04

NapK-60_80-mcrF12

NapK-60_80-mcrH04

NapK-60_80-mcrH06

NapK-60 80-mcrH08

NapK-60_80-mcrH10

NapK-60_80-mcrH12

NapK-100_120-mcrA02

NapK-100_120-mcrA06

NapK-100_120-mcrA08

NapK-100_120-mcrB02

NapK-100_120-mcrB04

NapK-100_120-mcrC02

NapK-100_120-mcrC06

NapK-100_120-mcrD08

NapK-100_120-mcrD12

NapK-100_120-mcrE04

NapK-100_120-mcrE06

NapK-100_120-mcrE08

NapK-100_120-mcrE12

NapK-100_120-mcrF02

NapK-100_120-mcrF04

NapK-100_120-mcrF06

NapK-100_120-mcrF08

NapK-100_120-mcrF10

NapK-100_120-mcrG02

NapK-100_120-mcrG06

NapK-100_120-mcrG08

NapK-100_120-mcrG10

NapK-100_120-mcrH02

NapK-100_120-mcrH10

NapK-100_120-mcrH12
F17.1 30A02 (AY324363)

Microcosm Enrichment, Monterey Canyon F17.1_30A02 (AY324363)

Microcosm Enrichment, Monterey Canyon F17.1 30A02 (AY324363)

Microcosm Enrichment, Monterey Canyon F17.1_30A02 (AY324363)

Microcosm Enrichment, Monterey Canyon F17.1_30A02 (AY324363)

Microcosm Enrichment, Monterey Canyon F17.1 30A02 (AY324363)

Microcosm Enrichment, Monterey Canyon F17.1_30A02 (AY324363)

Microcosm Enrichment, Monterey Canyon F17.1_30A02 (AY324363)

Microcosm Enrichment, Monterey Canyon F17.1 30A02 (AY324363)

Microcosm Enrichment, Monterey Canyon F17.1_30A02 (AY324363)

Microcosm Enrichment, Monterey Canyon F17.1_30A02 (AY324363)

Microcosm Enrichment, Monterey Canyon F17.1 30A02 (AY324363)

Microcosm Enrichment, Monterey Canyon F17.1_30A02 (AY324363)

Microcosm Enrichment, Monterey Canyon F17.1 30A02 (AY324363)

Microcosm Enrichment, Monterey Canyon SMI1-GC205-mcr12 (DQ521864)

Hypersaline Sediments, Gulf of Mexico GZfos_9_28.6 (AY324372)

Microcosm Enrichment, Monterey Canyon GZfos 928.6 (AY324372)

Microcosm Enrichment, Monterey Canyon F17.1_30A02 (AY324363)

Microcosm Enrichment, Monterey Canyon F17.1_30A02 (AY324363)

Microcosm Enrichment, Monterey Canyon F17.1_30A02 (AY324363)

Microcosm Enrichment, Monterey Canyon F17.1_30A02 (AY324363)

Microcosm Enrichment, Monterey Canyon SMI1-GC205-mcr12 (DQ521864)

Hypersaline Sediments, Gulf of Mexico F17.1_30A02 (AY324363)

Microcosm Enrichment, Monterey Canyon F17.1_30A02 (AY324363)

Microcosm Enrichment, Monterey Canyon F17.1 30A02 (AY324363)

Microcosm Enrichment, Monterey Canyon SMI1-GC205-mcr12 (DQ521864)

Hypersaline Sediments, Gulf of Mexico F17.1 30A02 (AY324363)

Microcosm Enrichment, Monterey Canyon F17.1 30A02 (AY324363)

Microcosm Enrichment, Monterey Canyon F17.1_30A02 (AY324363)

Microcosm Enrichment, Monterey Canyon F17.1 30A02 (AY324363)

Microcosm Enrichment, Monterey Canyon F17.1_30A02 (AY324363)

Microcosm Enrichment, Monterey Canyon F17.1 30A02 (AY324363)

Microcosm Enrichment, Monterey Canyon F17.1 30A02 (AY324363)

Microcosm Enrichment, Monterey Canyon GZfos_9_28.6 (AY324372)

Microcosm Enrichment, Monterey Canyon GZfos 928.6 (AY324372)

Microcosm Enrichment, Monterey Canyon F17.1_30A02 (AY324363)

Microcosm Enrichment, Monterey Canyon F17.1_30A02 (AY324363)

Microcosm Enrichment, Monterey Canyon F17.1 30A02 (AY324363)

Microcosm Enrichment, Monterey Canyon 
SM4. Closest relatives of representative clones from mcrA gene libraries from depths 40 to $60 \mathrm{cmbsf}$ (NapK-40_60), 60 to 80 cmbsf (NapK-60_80), 100 to 120 cmbsf (Napk-100_120) for the Napoli mud volcano. 